\title{
Societal Institutions and Tax Effort in Developing Countries ${ }^{*}$
}

\author{
Richard M. Bird
}

Business Economics, Rotman School of Management, University of Toronto International Center for Public Policy, Andrew Young School of Policy Studies, Georgia State University

Australian Taxation Studies Program (ATAX), Faculty of Law, University of New South Wales

\section{Jorge Martinez-Vazquez}

Department of Economics, Andrew Young School of Policy Studies, Georgia State University, Atlanta, Georgia (United States)

International Center for Public Policy, Andrew Young School of Policy Studies, Georgia State University, Atlanta, Georgia (United States)

Andrew Young School of Policy Studies, Georgia State University, Atlanta, Georgia

$$
\text { (United States); }
$$

REDE, Faculty of Economics and Management, University of Vigo, Vigo, Spain

$$
\text { and }
$$

Benno Torgler ${ }^{\dagger}$

School of Economics and Finance, Business School, Queensland University of Technology, Brisbane, Australia

The main theme of this paper is that a more legitimate and responsive state appears to be an essential precondition for a more adequate level of tax effort in developing countries. While at first glance giving such advice to poor countries seeking to increase their tax ratios may not seem more helpful than telling them to find oil, it is presumably more feasible for people to improve their governing institutions than to rearrange nature's bounty. Furthermore, improving social institutions, such as enhancing the rule of law and reducing corruption, may not take longer nor be necessarily more difficult than changing the opportunities for tax handles and economic structure, such as the relative share of the non-agriculture sector in the economy or the weight of imports and exports in GDP. The most important contribution of this paper is to extend the conventional model of tax effort by showing that not only do supply factors matter, but that societal institutions (demand factors) also determine tax effort to a significant extent. 


\section{INTRODUCTION}

"Will underdeveloped countries learn to tax?" asked Nicholas Kaldor (1963), forty years ago. Underlying this question is the assumption that if a country wishes to become 'developed' it needs to collect in taxes an amount greater than the 10-15 percent found in many developing countries. $^{1}$ Kaldor's answer to his question was essentially that since even the poorest country had sufficient 'capacity' in both economic and administrative terms to tax more, whether or not a particular country did so depended primarily on its political institutions. Would developing countries be fortunate enough to have those with political power voluntarily give up at least some of their power to block fiscal reform in exchange for social stability? Or would the ruling groups rather wait (in the spirit of après moi le deluge) for the revolutionary upheaval that he considered the only alternative (Kaldor, 1963)?

Most of the elements of the discussion of 'tax effort' in developing countries in recent decades are evident in this early discussion:

- Should these countries tax more than they do? Most who have studied this question seem to have assumed, as did Kaldor, that more taxation is just what the doctor ordered. ${ }^{2}$

- Can they tax more than they do? That is, do they have the 'capacity' to collect a relatively larger share of national income in government coffers? Early regression analysis at the IMF launched a flood of empirical studies considering this question, most of which agreed with Kaldor's conclusion that in economic terms such countries

- can indeed tax more, that is, that their 'capacity' to tax exceeds the 'effort' they make to tax that capacity. ${ }^{3}$ Conceptual underpinning for this emphasis on the importance of capacity in determining tax levels — that is, for assessing tax effort in terms of how much a country taxed relative to

\footnotetext{
* We are grateful to Michael Rushton, our discussant at the conference, and to other conference participants as well as Uri Raich and Francois Vaillancourt for helpful comments on earlier versions of this paper.

† The authors are, respectively, at the University of Toronto, the Andrew Young School of Public Policy, Georgia State University, and the University of Basel.

${ }^{1}$ Kaldor's contemporary, Sir Arthur Lewis (Martin and Lewis, 1956), a few years earlier had similarly argued that ... the government of an under-developed country needs to be able to raise revenue of about 17 to 19 percent of G.N.P ... in order to give a not better than average standard of service.

${ }^{2}$ In recent years, however, influenced perhaps by the growing empirical evidence of the 'costs' of taxation (as reviewed recently in Bird and Zolt, 2003), more analysts have come to share the early skepticism of Bauer (1955) as to the inherent virtues of channeling a larger share of national resources through the public sector. We do not, however, discuss this important question in the present paper.

${ }^{3}$ Tanzi (1987) is a good example of such work: for a skeptical appraisal of what can be learned from such studies, see Bird (1976).
} 
its measured capacity - was provided by Hinrichs (1963) and Musgrave (1969), who emphasized the importance of 'tax handles' or structural features such as imports which were relatively easy to tap for fiscal purposes.

- Although some literature stresses the limits administrative capacity imposes on taxation in developing countries (Bird, 1989), those who advocate more taxation as an essential ingredient of any lasting solution to underdevelopment have seldom been deterred by such skepticism. In a sense they seem right in ignoring this problem since the evidence appears to suggest that, if the political will to tax is there, the administrative way to do so can be found, if not immediately then shortly. ${ }^{4}$

- Indeed, as again Kaldor (1963) explicitly noted, one of the principal lessons that has been learned from tax reform experience around the world is precisely that 'political will' is the sine qua non of any successful tax reform (Bird, 2004) and that a country's tax system reflects its political institutions. In the words of Rodrik, Subramanian, and Trebbi (2002) it appears that "Institutions Rule" in this as in other areas of economic development.

The problem thus seems obvious: if poor countries want to become richer, they need to spend more on public infrastructure, education, and so on. Hence they need to tax more. The main reason they do not do so also seems obvious: it is not in the interest of those who dominate the political institutions of such countries to increase taxes. If this is the story, then economists, who do not readily take to the revolutionary barricades, have a problem in suggesting a viable solution. The emphasis in earlier empirical analysis on 'supply side' factors such as the ready availability of (easily taxed) economic activities such as foreign trade and mining remains important in explaining what countries do, but telling a country that wants to raise its tax levels to find oil is not a particularly promising piece of policy advice. Is the recent political economy literature on the importance of institutions more useful in this respect? Are 'societal institutions' (Alm and Martinez-Vazquez, 2003) the key to increasing tax effort? What institutions? Can such institutions be modified to produce more 'pro-fiscal' outcomes (assuming for present purposes that this is desirable)? In this paper, we explore some aspects of these broad questions, taking two distinct approaches. $^{5}$

In Section 2 we take a sort of case study approach to the problem, first sketching the broad experience with tax reform in Latin America and the relatively unsuccessful outcomes - if success is defined in terms of increas-

\footnotetext{
${ }^{4}$ For example, this is essentially the conclusion drawn in the review by Bird and Casanegra (1992).

${ }^{5}$ We do not, however, attempt a formal 'political economy' analysis of the problem: see, for example, Cheibub (1998) and Hettich and Winer (1999).
} 
ing the tax-GDP ratio - of these efforts. Some seem surprised by this lackluster performance, but, as did Kaldor (1963), we argue that this outcome is only to be expected since the underlying political conditions in these countries have not, for the most part, changed significantly over this period. We develop this proposition with reference to Mexico's experience over the past few decades.

In contrast, in Section 3 of the paper we take a quite different approach, examining empirically the determinants of tax levels across a broader sample of developing and transition countries. In doing so, we take into account not only the supply factors (tax handles) but also such critical demand factors as institutions, the size of the shadow economy, wealth inequality and 'tax morale' (defined as the intrinsic motivation by citizens to pay taxes, which, it is argued, depends on their attitude toward the state, see, e.g., Frey 1997). If taxpayers perceive that their interests (preferences) are properly represented in political institutions and they receive an increased supply of public goods, their willingness to contribute increases. On the other hand, a state in which corruption is rampant is one in which citizens have little trust in authority and thus a low incentive to cooperate. A more encompassing and legitimate state may be an essential precondition for a more adequate tax system in developing countries. Societal institutions in this sense might be seen as an indicator of the extent to which citizens feel they have a meaningful 'voice' in influencing the state. At the same time, however, the level of taxation can also be expected to be related to the availability of what may be called the 'exit option' ${ }^{6}$ of the so-called shadow economy. In general, the larger the shadow economy, the lower we would expect tax effort to be.

In different ways, the distinct approaches taken in Sections 2 and 3 point to the same conclusion, set out briefly in Section 4. A more encompassing and legitimate state is an essential precondition for a more adequate tax system in developing countries. While at first glance giving such advice to poor countries may seem no more helpful than telling them to find oil, it is presumably more feasible for people to improve their governing institutions than to rearrange nature's bounty. ${ }^{7}$

\footnotetext{
${ }^{6}$ Both the 'exit' and 'voice' options are beautifully set out in Hirschman's (1971) seminal study.

${ }^{7}$ We neglect here one obvious alternative way out of this dilemma, namely, military conquest of those more blessed by nature: for a recent exploration of some interesting aspects of this theme, see Teng (2001). We also neglect the obvious fact that many countries rich in natural resources also do not make much tax effort and those that do, often make poor use of the resources thus obtained (Davis, Ossowski, and Fedelino, 2003).
} 


\section{THE TAX RATIO AND POLITICAL EQUILIBRIUM}

Over the last forty years, most Latin American countries found it difficult to achieve a sustainable policy balance in the face of the often conflicting and frequently changing forces, external and internal, economic and political, that most of them have faced. Both the facts that presumably should govern policy in principle and the intellectual fashions that too often seem to govern it in practice have changed markedly over the last few decades in most countries in the region. It is thus not surprising that their tax policies have also changed considerably - though less either in level or in structure than might be expected.

\subsection{Taxation in Latin America}

The data on taxation in Latin America, partial and in many ways unsatisfactory as they are, suggest several interesting conclusions. ${ }^{8}$

- First, over the last few decades taxes have not gone up in Latin America. Some rates have risen, mainly for VAT, but many have declined, mainly for income taxes. Indeed, tax collections as a share of national income have, on average, actually declined a bit. In this sense, the tax effort of most Latin American countries has changed little. Latin American countries continue to be below average in terms of the size of their public sectors relative to their levels of per capita income (IDB, 1998).

- Secondly, those countries that had relatively high taxes at the end of the 1970s were still above the regional average in the 1990s, just as those that depended more on income than on consumption taxes continued on the whole to do so. To take two small examples, in 1980-82 Guatemala's tax ratio (taxes as a percent of GDP) was 9.8 percent, of which only 2.8 percent came from personal income taxes; in 1995-99, the comparable figures were 8.9 percent and 2.2 percent. At the other extreme, although Nicaragua's tax ratio rose from 23.6 percent in 1981-83 to 26.2 percent in 1995-99, the share of taxes on domestic consumption remained dominant, although declining a bit from 49 percent to 46 percent. ${ }^{9}$ Of course, tax rates in these countries did not necessarily change in the same way as tax ratios: for example, the VAT rate in Nicaragua rose from 6 to 15 percent over this period.

- Thirdly, although the reality of taxation in Latin America has changed less than our perception of it, as evidenced by the relative constancy in both tax levels and tax structures across and within countries, many changes have taken place in tax policy across this complex region over the last few decades. Economic and political circumstances have changed dramatically

\footnotetext{
${ }^{8}$ For data, and a fuller discussion, see Bird (2003).

${ }^{9}$ The figures for the earlier period are from Tanzi (1987); the more recent figures are from Stotsky and WoldeMariam (2002).
} 
at times in some countries, and sometimes tax systems have changed with them, though not always as one might expect.

In a recent analysis of Mexico, for example, Martinez-Vazquez (2001) notes that one of the most striking features of the various major tax changes that have taken place over the decades has been how very little apparent effect they have had on Mexico's tax-GDP ratio, which has remained almost constant. Tax policy and tax administration reforms over the last two decades have given Mexico a tax structure that is in many ways comparable to that in many developed countries but the tax system has continued to perform poorly in raising adequate revenues. ${ }^{10}$

Mexico's tax effort has not changed significantly for a quarter of a century. Both total federal revenues (which exclude social security funds and subnational governments) and federal tax revenues (which exclude oil and other non-tax revenues) as percent of GDP have moved up and down over the last two decades but have remained relatively stable overall, averaging between 15 and 16 percent for total federal revenues and between 10 and 11 percent for tax revenues. From 1980 to 2003, tax revenues rose only from 10.9 percent to 11.3 percent of GDP, and total federal revenues only went up from 15.3 percent to 16.8 percent. ${ }^{11}$

Given the marked improvements in the tax system over the past three decades (Martinez-Vazquez, 2001), it is surprising that Mexico's tax system has not been able to generate more than 11 percent of GDP in tax revenues particularly since the most common objective of the various tax reforms over this period, including the latest attempted reform by President Vicente Fox at the start of his administration in 2000, has been to increase the revenue adequacy of the tax system in order to be able to improve the quality and quantity of public services.

As discussed below, any country's tax performance can be explained in part by factors common to many other countries. In addition, however, country-specific factors may contribute significantly to explaining revenue

\footnotetext{
${ }^{10}$ This statement does not represent a normative judgment of the fiscal performance of Mexico. The share of government in GDP reflects, among other things, the collective preferences of a country for public goods and services vis-à-vis private consumption. From an economic standpoint, these preferences cannot be judged right or wrong. Nonetheless, the general consensus in Mexico is that the current level of revenues is insufficient to support the expenditure programs desired.

${ }^{11}$ The overall adequacy of revenues can be further illuminated by examining the behavior of the government budget deficit. The sustained deficits during the 1980s may indicate that Mexico's level of tax effort was too low to cover the level of expenditures desired by the government. The budget imbalance during the 1980 s was very pronounced. Closing a deficit of 10 percent of GDP would have required practically doubling the existing level of tax effort. But clearly the same conclusion does not apply to the 1990s. The very small budget deficits since 1993 may suggest either that Mexico has reached some sort of equilibrium vis-à-vis its desired level of tax effort or that other forces have been able to impose fiscal discipline in the federal budget.
} 
performance. One set of country-specific factors, for example, relates to the management of tax policy. The good fundamental structure of Mexico's tax system and its revenue performance has been undermined by numerous ad hoc policy measures. With respect to the tax on enterprise profits, for instance, several economic sectors, including all agriculture and transport, benefited from a special regime in which the tax base was calculated on a cash-flow basis and agriculture and some other sectors also benefited from a tax rate half that applied under the general corporate income tax regime. These and many other exceptions to the supposedly general income and sales taxes added excess burdens, cost revenues, and by undermining the confidence of taxpayers in the fairness of the system probably reduced voluntary compliance.

A second set of country-specific factors has to do with the management of tax enforcement. Tax administration in Mexico has faltered in part because tax policy measures have ignored the ability of the tax administration to enforce complex tax issues and in part because the tax administration has failed to modernize and may in some respects even have gone backwards with respect to some of the institutional improvements achieved in earlier periods. An example of putting the "cart of tax policy" before the "horse of tax administration" is Mexico's liberal use of such complex consolidation rules for dependent enterprises that in effect it wrote almost a blank check for a powerful group of taxpayers (about 350 consolidated groups involving 5,000 separate companies).

Finally, and importantly, despite frequent general pronouncements about the need for higher revenue collections, Mexico seems at times to have pursued a policy - sometimes explicitly - of keeping the ratio of revenues to GDP relatively constant. A relatively constant tax effort has been achieved in two ways. First, any increase in revenues resulting from economic growth, enlargement of the tax bases, or increased petroleum revenue was generally followed by such discretionary tax policy measures as lower tax rates with the result of keeping actual tax effort more or less constant. During the 1980s, for instance, a reverse or mirror image of revenue movements from petroleum and non-petroleum sources was evident. The chronology of tax concessions parallels periods in which the automatic elasticity of the system would otherwise have produced an increase in revenue effort. ${ }^{12}$ Alternatively, at times there has been discretionary relaxation or tightening of tax administration effort. The political economy of taxation in Mexico has long involved periodic discussions and agreements between the government and a more or less willingly compliant compact

\footnotetext{
${ }^{12}$ It has been a common, although not explicitly stated, policy within the Ministry of Finance during much of the last two decades that any increase in revenues should be spent by the Ministry itself in the form of rate reductions or tax expenditures rather than on the expenditure side of the budget by line ministries and other budget units.
} 
of large taxpayers whose general tax burden was, in effect, 'negotiated'. The point is not so much that tax enforcement efforts were relaxed when government revenues were up, but more that high concentrated levels of enforcement were launched (in the from of "tax crusades" and so on) only when government revenues were dramatically down due to economic crises and business cycle downturns.

At least in the case of Mexico, then, it appears that reforms in tax structure (1) may have been undermined by unrelated ad hoc measures, or (2) they may have been offset by administrative deterioration, or (3) one or both of the preceding may have occurred less by accident than by intention. Similar relative constancy can be seen in other countries (e.g. Colombia) over the decades despite repeated tax reforms (McLure and Zodrow, 1997) ${ }^{13}$ Perhaps, it appears, a 'good' tax reform — one intended to raise more revenue in a more efficient and equitable fashion, for instance - may be something like a 'good' seat belt law. That is, if everything else stayed the same, lives would be saved (the tax ratio would increase), but things do not stay the same - some people drive faster when they are belted in, so death rates (tax ratios) show little change. In short, countries may tend to achieve an equilibrium position with respect to the size and nature of their fiscal systems that largely reflects the balance of political forces and institutions, and stay at this position until 'shocked' to a new equilibrium.

\subsection{Why So Little Change?}

Two alternative explanations are obviously possible as to why so much tax 'reform' has had so little effect on tax 'effort'. Either 'supply' ('capacity') factors have altered over the period in such a way as to offset all attempts to raise tax ratios. Or, perhaps more plausibly, ideas as to what the 'proper' tax level should be have altered over time. The two main aims of most tax reforms in the period after the Second World War were first, to raise revenue - and lots of it - in order to finance the state as the 'engine of development', and, second, to redistribute income and wealth. Since then as now income and wealth were markedly unequally distributed in Latin America, the need for redressing the balance through fiscal means seemed obvious to all, and the ability of taxes to do the job was largely unquestioned. Both goals - revenue and redistribution - could, it was generally thought, be achieved largely by imposing high effective tax rates on income, essentially because the depressing effects of taxes on investment and saving were considered to be small. Indeed, an extra bonus of high

\footnotetext{
${ }^{13}$ This phenomenon is by no means confined to Latin America, of course: a striking example elsewhere appears to be India where, after a quick rise in the tax ratio following liberalization in the early 1990 s, matters seem to be settling back to the lower ratio to which the country had long been accustomed.
} 
rates was sometimes argued to be that they made it easier to lead balky private investors by the visible hand of well-designed fiscal incentives into those channels most needed for developmental purposes.

To exaggerate only a bit, the conventional wisdom at the time was essentially that all developing countries needed to do to solve their fiscal problems was to "learn to tax" (Kaldor, 1963), which to most meant to tax in a properly progressive fashion. Views on the appropriate role and structure of taxation began to change in the 1970s and 1980s, however. By 1990, in contrast to the immediate post-war era, both economists and policy-makers had generally come to believe that high tax rates not only discouraged and distorted economic activity but were largely ineffective in redistributing income and wealth. Reflecting this new view, income tax rates on both persons and corporations were cut sharply and are now almost universally in the 20-30\% range in Latin America, as elsewhere in the world (Shome, 1999). On the other hand, reflecting - indeed, to some extent leading - world-wide trends, the VAT is now the mainstay of the revenue system in Latin America (Ebrill et al., 2001). Moreover, the decline of taxes on international trade with liberalization and the WTO as well as increased competition for foreign investment have moved international concerns from the bottom to the top of the tax policy action list in many countries. At the same time, in many countries, a new issue has risen to prominence on the fiscal menu as decentralization made the question of setting up adequate sub-national tax systems an increasing concern, not least in Latin America (IDB, 1997). Life in the tax policy world in Latin America, as elsewhere, was thus very different in many respects at the beginning of this century than it was in the middle of the last century.

\subsection{Ideas, Institutions, and Interests}

Such ideas matter. As Blyth (2002, p. 274) says, "... neither material resources nor the self-interest of agents can dictate ... ends or tell agents what future to construct. Ideas do this." Or, in the more colorful words of John Maynard Keynes (1936, pp. 283-84): "practical men, who believe themselves to be quite free from any intellectual influences, are usually the slaves of some defunct economist ... soon or late, it is ideas, not vested interests, which are dangerous for good or evil". Ideas about tax policy have clearly changed. Have institutions and interests also changed?

Some years ago, Michael Best (1976) analyzed Central American tax policy in essentially a 'class' framework, arguing that in principle changes in tax level structure (e.g., the degree of emphasis on income taxation) reflected largely the changing political balance of power between landlords, capitalists, workers, and peasants. Shortly after his article appeared, the Sandinista government - perhaps the most explicitly leftist regime ever to have power in the region (apart from Cuba) - took over in Nicaragua. 
What happened to taxes? First, as Best (1976) would have predicted, the tax ratio rose very quickly, from 18 to 32 percent of GDP within the first five years of the Sandinista regime. Secondly, however, almost all the increased tax revenue came from regressive indirect taxes, not the progressive income taxes that one might have expected. Third, and in many ways most interesting, once Nicaragua's tax ratio was increased, it stayed up there even a decade (and three subsequent governments) after the defeat of the Sandinistas. ${ }^{14}$

As this example suggests, politics matters in taxation, but it does not necessarily dominate. Economic and administrative realities, and ideas, also matter. The fiscal reality found in most countries probably reflects a changing mixture of ideas, interests, and institutions. The tax structure that exists seldom seems to have been designed with any particular objective in mind. On the contrary, it often seems, like Topsy, to 'have just growed' in ways shaped by both the changing local environment and the changing external context. In the case of the United States, for example, as Weisman (2002, p. 366) notes, "economic crises and wars helped create a consensus for an income tax that falls most heavily on the wealthiest taxpayers. The consensus [was] forged in the period of 1860 to 1920 ..." The lengthy debate about taxes that took place over this period was, he says, not really about taxes at all but rather about "what kind of society Americans wanted". Since 1970 or so, the ideas on the relevant balance between taxes and society that were forged over the first half of the 20th century seem to many to have changed; the reality, however, has changed much less and is perhaps not likely to change all that much in the near future.

Recent broader historical and comparative analysis broadly supports this argument. ${ }^{15}$ Lindert (2002), for example, suggests that democratic polities do learn from experience, and do, over time, tend to reward more those parties that follow more prudent economic policies. Cheibub (1998) demonstrates that even new democracies have frequently raised taxes. Those who

\footnotetext{
${ }^{14}$ Peacock and Wiseman (1967) many years earlier had explained a similar discrete jump in tax effort and public expenditure in Great Britain as a 'displacement effect': general perceptions about what is a tolerable level of taxation tend to be quite stable until these perceptions get shocked by social upheavals, and levels of taxation that would have been previously intolerable become acceptable and remain at that level after the social perturbations have disappeared.

${ }^{15}$ See Bird (2003) for an extended discussion. One might perhaps question the relevance of historical or even comparative experience in analyzing and understanding the problems of developing countries today. As a recent book notes, however, "Today's industrialized countries were yesterday's developing or transitional economies and for tax policy purposes the demarcation line between them is more likely to be the relative efficiency and integrity of the tax administration, rather than such economic criteria as GDP per capita" (Messere, de Kam, and Heady, 2003, preface). Of course, how a tax administration functions is determined largely by more fundamental political factors.
} 
think that populists who promise immediate delivery of the moon to the voters will invariably win should, it seems, consider more carefully the meaning of Abraham Lincoln's famous dictum to the effect that one can fool all of the people some of the time and some of the people all of the time, but that one can never fool all of the people all of the time. Economic history appears to tell us that, at least in societies with the error-correction mechanism that we call "democracy", Lincoln was right, at least to some extent. As Blyth (2002, p. 274) puts essentially the same point: "Political economies ... are ... evolutionary systems populated by agents who learn and apply those lessons in daily practice".

\subsection{How to Tax More}

What do such arguments suggest with respect to increasing tax effort in Latin America or in developing countries more generally? Weisman (2002, p.366) concludes with respect to the United States that "... the search for the right balance is an endless process.... The consensus supporting the legitimacy of the income tax is likely to remain undisturbed. But its progressive nature will always be debated as long as we care about reconciling the competing demands of social equity, economic incentives and the need to pay for an expanding government." In Latin America, no real consensus on the 'right balance' appears yet to have been achieved in most countries. The fact that a few developed countries may have, as it were, moved on to a new, less progressive consensus does not imply that it is any less important for Latin America to develop its own viable democratic social consensus on the right balance between equity and efficiency in taxation.

The developed countries have clearly reached different equilibrium positions. Lindert (2003) may be seen in large part as an extended demonstration of the continued viability of the so-called 'welfare state' model in most European countries and a different, lower-tax equilibrium in the U.S. and a few other countries. As Messere, de Kam, and Heady (2003) show, there has been essentially no convergence in either tax levels or structures among OECD countries in recent decades. They argue there is little reason to expect such convergence in the near future. Equally, there is no reason to expect any one balance to be right for all countries developing countries, in Latin America or elsewhere. As always with public policy, no one size fits all. What is right, or at least feasible, in Chile or Brazil, for example, is likely to continue to differ from what may be sustainable in Colombia or Honduras.

What matters is not only how high taxes are (revenue adequacy), but also how the tax level has been chosen, how the taxes are imposed, and how the funds thus raised are used The historical evidence appears to suggest that it is critical to ensure that the linkage between expenditure and revenue 
decisions is clearly established in the budgetary and political process. ${ }^{16}$ As Wicksell (1896) argued over a century ago, allocative decisions in the public sector will be made efficiently only if they are financed efficiently that is, by benefit taxes, which may be broadly understood in this context as taxes deliberately chosen to finance specific expenditures in the full knowledge of the allocative consequences of both expenditures and taxes. Wicksell further argued that even such good taxes would really only be politically sustainable if the distribution of income and wealth accorded broadly with the politically-acceptable "just" distribution of income which, as Alesina and Angeletos (2003) demonstrate, may be very different in different countries.

In many ways, then, the central question of tax policy is how to make the "wicksellian connection" (Breton, 1996) operational so that good decisions - that is, decisions that reflect people's real preferences as closely as practically feasible, - are made on both sides of the budget. The key to good fiscal outcomes lies less in any particular budgetary or financing procedure than in implementing a public finance system that, to the extent possible, links specific expenditure and revenue decisions as transparently as possible. The best that can be done to help the relevant decision-makers make the right decision is to ensure that they and all those affected are made as aware as possible of all the relevant consequences. For a country to implement a better tax system — better in the sense of giving the people what they want - it must have a better political system that transmutes citizen preferences into policy decisions as efficiently as possible. "Democracy", as Churchill reportedly once said, "is the worst form of Government except all those other forms that have been tried from time to time." 17

Of course, taxation is always and everywhere a 'contested concept' ( $\mathrm{S}$ abates and Schneider, 2003). Some pay; some don't pay. Some pay more than others. Some receive compensating services; some do not. Such matters are, in democratic states, resolved through political channels. Indeed, history suggests that the need to secure an adequate degree of consensus from the taxed is one of the principal ways in which, over the centuries, democratic institutions have spread. No non-dictatorial government in this age of information and mobility can long stay in power without securing a certain degree of consent from the populace, not least in the area of taxation. State legitimacy thus rests to a considerable extent on citizen-

\footnotetext{
${ }^{16}$ The discussion here focuses on (non-benefit) taxation. To the extent public expenditures are financed from charges, non-tax revenues, and borrowing, other considerations may come into play but these issues cannot be discussed adequately here.

${ }^{17}$ As Lindert (2004) shows, this quotation actually had a somewhat different implication in its original context, but it is nonetheless largely right if one is concerned with growth: as Lindert (2004, p.344), concludes, history tells us that "the average democracy has been better for economic growth than the average autocracy...."
} 
s' 'quasi-voluntary compliance' (Levi, 1988) with respect to taxation. To secure such compliance, tax systems must, over time, in some sense represent the basic values of at least a minimum supporting coalition of the population (Hettich and Winer, 1999).

No matter how good political institutions may be, however, countries will always encounter difficulties in dealing with distributive issues. How one thinks about taxes and inequality reflects ideas of fairness or social justice, and different people invariably have different beliefs about what is fair beliefs that may, or may not, have some objective basis. People may have different beliefs for many reasons: because they do not know the truth, because no one knows the truth, because they have been misled about the truth, or just because they see things differently. Successful politicians are those who can manage such conflicts, and one way to do so, as discussed earlier, is by making the wicksellian connection as plausible as possible to most people. Unless this is done satisfactorily, the long-term political sustainability of any tax system remains questionable.

\subsection{Latin America Revisited}

The central social and economic problem in many Latin American countries is still clearly inequality (de Ferranti et al., 2004). On the other hand, the key, and related, governance problem is lack of accountability. A good tax system is critical to the solution of both problems. Reforms that link taxes and benefits more tightly, such as decentralization and more reliance on user charges, may help accountability. The most important function of the tax system in most countries, however, is simply to provide (noninflationary) funding for pro-poor and pro-growth spending programs e.g. in improving human capital, and the best way to do so is probably through a broad-based non-distortionary consumption tax, as has long been recognized. It is of course easy to think of ways to tax the rich more effectively, and there are certainly good reasons to do so in countries in which many assets of the wealthy are underutilized and many incomes of the rich may reflect rents secured through political connections or monopolies. Nonetheless, as IDB (1998) stresses, attempts to impose unduly redistributive taxes may backfire, and countries that follow this path may end up with public sectors that are both smaller and less redistributive. ${ }^{18}$

What is actually done will of course be determined in the political arena. Countries vary enormously in the effectiveness and nature of their political systems. Some may be close to 'failed states' in which institutions are so ineffective that it does not matter much what is attempted. It will not work. Others may be 'developmentalist' (as in the early CEPAL model) and want to use their fiscal systems largely as interventionist instruments.

\footnotetext{
${ }^{18}$ In any case, as Harberger (2003) shows, even the most redistributive tax will not in itself have any much effect on income redistribution.
} 
Still others may be of a more laissez-faire disposition. Some may be more populist, some more elitist, some more predatory.

The dominant policy ideas in different countries — about equity and fairness, efficiency, and growth - like the dominant economic and social interests - capital, labor, regional, ethnic, rich, poor - and the key institutions - political (democracy, decentralization, budgetary) and economic (free trade, protectionism, macroeconomic policy, market structure) - all interact in the formulation and implementation of tax policy. This changing interplay of ideas, interests, and institutions over time affects the level of taxation, the structure of taxation, and many of its critical details such as the progressivity of rates.

Indeed, taxation is probably one of the clearest arenas in which to witness the working out of these complex forces. Suppose, for example, that both the public at large and the elite want changes, for different reasons. The elite can always manipulate the state to some extent and may use public concern as 'cover' to achieve its own ends. Consider, for instance, the sad story of property taxation. Once seen as the bulwark of local democracy and accountability, this tax has, over time, come to be considered by the public in the U.S. to be regressive and unfair (Youngman, 2002), thus fostering elite interests in lowering the tax burden on an asset base they disproportionately control. The spillover of anti-property tax rhetoric into more unequal societies to the south has made it even more difficult to institute not only the kinds of specific land taxes that might in principle contribute to land reform (Dorner, 1992) ${ }^{19}$, but even the low-rate effective property taxes needed to finance local governments. There remains, of course, a great deal that we do not understand about these complex matters. What seems clear from the work done to date on the political economy of taxation, however, is that while taxes definitely matter in both economic and political terms, they are more driven by than drivers of social and economic conditions.

Viewed from this perspective, Latin America and indeed much of the developing world has yet to experience even the earlier parts of the cycle that produced the (more or less) redistributive and (more or less) growthfacilitating fiscal states, whether of the U.S. or E.U. variety, now found in developed countries - the long preparatory period during which the idea of the desirability, and even necessity, of a larger fiscal system becomes established. Instead, bypassing this 'egalitarian' period, some countries in Latin America seem to have moved directly from the feudal inequality of landbased maldistribution to the modern era of capital-based maldistribution. Doreen Warriner (1969) once said, despairingly, that most Latin Americans

\footnotetext{
${ }^{19}$ Although one might rightly be skeptical about the effectiveness of such measures (Bird, 1974).
} 
did not seem to know what a good land reform means — probably because they had never seen one. Equally, one might perhaps speculate that, in most countries of the region, as Engerman and Sokoloff (2001) almost but not quite - say most people may not really know what moderate or justifiable inequality means, since they have never seen it.

Governments in many Latin American countries are in dire straits. Even those that have reached relatively safe harbors politically, and have a certain degree of legitimacy and stability, almost always feel - often correctly - that they are in an economically precarious situation. The budget is politically and economically constrained. Life is difficult. Nothing can be done. All this may be true to some extent, but it is also both too much a counsel of despair and too easy a way out. Even in the most hopeless situations, something usually can be done to improve matters. There will always be dispute over exactly what should be done to improve tax systems. Unless and until an adequate degree of political consensus on what should be done is achieved, however, no significant changes in either tax structure or tax levels seem likely.

As Lledo, Schneider, and Moore (2003, p. 47) stress, the key problem in Latin America is that most countries lack "...an (implicit) social contract between governments and the general populace of the kind that is embedded in taxation and fiscal principles and practices in politically more stable parts of the world." What needs to be added to this bleak but accurate assessment is that history tells us that such principles generally do not become embedded either painlessly or quickly. The specific substantive suggestions that Lledo, Schneider, and Moore (2003) make to improve matters - more use of income taxes, better VAT administration on a broader base, more attention to subnational taxation, more attention to informal activities and environmental aspects of taxation, closer ties to expenditure policy, and so on - are of course already the stuff of countless existing reports. Who can argue?

The real question is why so little has been done. From this perspective, by far the most important conclusion of Lledo, Schneider, and Moore (2003)

— which is also in many ways the main point of the present section - is their final recommendation "to improve political institutions in ways that enhance legitimacy and capacity." In other words, there can, so to speak, be no good taxation without good representation. The trouble with this truism is that history suggests that all too many countries have proved unable to achieve either good taxation or good representation without first going through a period of bad taxation which, in Hegelian fashion, called forth forces that in the end improved both representation and taxation. In this perhaps somewhat perverse sense Latin Americans (and those in many developing countries around the world) may be a bit luckier than first appears since they have a lot of bad taxation with which to begin. 


\section{THE ROLE OF SOCIETAL INSTITUTIONS: CROSS COUNTRY STATISTICAL EVIDENCE}

In Section 2, we argued that how much any society collects in taxes to a considerable extent reflects what we called its 'political equilibrium' and that its level of tax effort was not likely to change drastically unless the underlying forces determining that equilibrium level also changed. In this section we probe more deeply into the conditions under which tax effort can be increased by examining empirically the determinants of tax effort across a broad sample of developing and transition countries. We take into account not only 'supply factors' (tax handles) but also critical 'demand factors' such as societal institutions like governance and corruption, and 'framing' institutions such as the size of the shadow economy, inequalities in the distribution of income and 'tax morale'. Our basic working hypothesis is that supply factors matter but that in order to explain international differences in tax ratios we also need to take into account demand factors. In econometric terms, our hypothesis implies that the group of variables representing the role of societal institutions is statistically different from zero. That is, the tax level in any country does not just depend on the ability of its tax administration to collect taxes from the available 'tax handles'. If taxpayers perceive that their interests (preferences) are properly represented in political institutions and consider government to be not wasteful but helpful, their willingness to vote for higher levels of taxation and comply with their tax obligations will increase. Societal institutions' are used here as an indicator of the extent to which citizens feel they have a meaningful 'voice' in influencing the state. In general, the greater 'Voice,' other things equal, the higher we would expect tax effort to be. At the same time, the larger the shadow economy — the 'exit option' — the lower we would expect tax effort to be. An important contribution of this paper is thus to extend the basic tax effort model by establishing the extent to which institutions matter.

A. The Basic Model: Tax Handles and Determinants

We begin by re-examining the role of the traditional supply side variables of the tax effort literature. (An overview and summary of this literature is provided in Annex Table 1.) In general, this literature posits the following equation:

$$
T E=f(Y, P O P, X M, N A G R)
$$

where,

$T E$ : Tax effort

$Y$ : GDP per capita (measured in $\$ \mathrm{US}$ )

$P O P$ : rate of population growth

$X M$ : ratio of exports plus imports to GDP

$N A G R$ : non agriculture share of GDP 
We measure the dependent variable (Tax Effort) in two different ways: (a) tax revenue as a share of gross domestic product (GDP) - the traditional measure in the literature - and (b) current revenues/GDP (excluding grants). Current revenue includes all revenue to the central government from taxes and non-repayable receipts (other than grants), measured as a share of GDP. ${ }^{20}$ We call the second measure revenue effort, reserving the label of tax effort for the first measure. The use of the two measures of dependent variable provides for a more robust testing of the model, given different practices and possible mistakes in revenue classification in developing and transitional countries. Data for both measures of the dependent variable comes from the World Development Indicators (WDI) for 2003. Descriptive statistics for the two dependent variables are shown in Annex Table 2 . The two measures are highly correlated $(r=0.84$, statistically significant at the 0.01 level). The model is estimated using cross-section data with mean values for the years 1990 to 1999 for 110 developing and transitional countries. ${ }^{21}$ (Data sources and the description of all variables are summarized in Annex Table 3).

The explanatory variables employed in the basic model follow those used in the conventional tax effort literature. Per capita GDP is a proxy for the level of development of a country. A higher level of development goes together with a higher capacity to pay and collect taxes, as well as a higher relative demand for income elastic public goods and services (Chelliah, 1971; Bahl, 1971). In general, we would expect a positive relation between the level of per capita income and the level of tax effort.

Demographic characteristics may also be an important determinant of tax effort. As Bahl (2003, p. 13) points out, in countries with faster growing populations tax systems may lag behind in the ability to capture new taxpayers. This suggests that the rate of population growth is negatively related to the level of tax effort.

The most traditional explanatory variables in the conventional tax effort literature are those controlling for a country's economic structure. These variables reflect the idea that the availability of 'tax handles' should influence the level of tax effort. For example, trade taxes are often a major source of government revenues in less developed countries because they are easier to collect than income taxes. We measure the availability of this tax handle by openness, defined as the sum of exports and imports as a share of GDP. The tax ratio is expected to be positively related to the degree of openness of the economy.

\footnotetext{
${ }^{20}$ Note that since only central government data are recorded in this source, the tax level may be understated significantly in countries in which subnational governments are important.

${ }^{21}$ The use of average values over a period allows maximizing the number of observations.
} 
The sectoral composition of domestic product may also affect the ability to tax. A traditional measure signaling the difficulty to tax domestic output is the share of agriculture in GDP. Some argue that the agricultural sector is not much more difficult to tax (Bahl 2003), but the larger its relative importance in a country's economy the lower the need to spend on governmental activities and services, as many public sector activities are city-based (Tanzi 1992). In addition, for political reasons some countries exempt from taxes a large share of agricultural activities. A higher non-agriculture share in GDP should thus produce a higher tax ratio.

Table 1 contains our results for the conventional model. Estimated coefficients for the explanatory variables are in line with predictions for both measures of the dependent variable and largely coincide with previous findings in the literature. A faster rate of population growth leads to a lower tax ratio. A higher share of non-agricultural sector is correlated with a higher tax effort. The coefficient for GDP per capita has the predicted sign in two estimations and is statistically significant in one equation, but again these results are in line with previous studies (see Annex Table 1) ${ }^{22}$. However, openness of the economy is not associated in our results with a higher tax effort. ${ }^{23}$

Interestingly, in Eq. 3a and 3b we observe that Latin American countries have a statistically significant lower tax ratio than other developing and transition countries. This finding gives empirical support to the arguments developed in Section II regarding the unsuccessful outcomes in Latin America.

B. The Extended Model: The Role of Societal Institutions

The traditional literature on tax effort has ignored the role of demand factors such as societal institutions in explaining relative revenue performance. As noted above, our basic working hypothesis is that while supply factors clearly matter in order to explain international experience we also need to account for citizen attitudes to both their voice and exit options. We thus extend the "basic tax effort model" as:

$$
T E=f(Y, P O P, X M, N A G R, I N S T I T),
$$

where INSTIT is a vector of variables representing "demand factors" or societal institutions. Empirically, the additional exploratory variables we use can be grouped as follows:

\footnotetext{
${ }^{22}$ We explored the possibility of a non-linear relationship between GDP per capita and tax effort by adding the square of GDP per capita to the equation. However, the coefficient for the new term was generally not significant.

${ }^{23}$ As many countries have proceeded over the past several decades to lower tariff rates as part of their liberalization and economic reforms policies and joining the WTO, the strong link in the past between international trade and revenue collections may have weakened in more recent times.
} 
TABLE 1.

The Traditional Determinants of Tax Effort

\begin{tabular}{|c|c|c|c|c|c|c|c|c|}
\hline $\begin{array}{l}\text { Model } \\
\text { Dependent Variables }\end{array}$ & \multicolumn{2}{|l|}{\begin{tabular}{|l} 
OLS \\
Tax Effort
\end{tabular}} & \multicolumn{2}{|c|}{$\begin{array}{l}\text { OLS } \\
\text { Revenue Effort }\end{array}$} & \multicolumn{2}{|l|}{\begin{tabular}{|l} 
OLS \\
Tax Effort
\end{tabular}} & \multicolumn{2}{|c|}{$\begin{array}{l}\text { OLS } \\
\text { Revenue Effort }\end{array}$} \\
\hline & Eq. 1a & & Eq. 1b & & Eq. 3a & & Eq. 3b & \\
\hline Independent Variables & Beta & t-Stat. & Beta & t-Stat. & Beta & t-Stat. & Beta & t-Stat. \\
\hline a) DEVELOPMENT & & & & & & & & \\
\hline GDP PER CAPITA & 0.075 & 0.58 & $0.238^{* *}$ & 1.99 & $-0.278^{*}$ & -1.89 & -0.135 & -1.04 \\
\hline $\begin{array}{l}\text { POPULATION GROWTH } \\
\text { b) OPENNESS }\end{array}$ & $-0.435^{* * *}$ & -4.10 & $-0.329^{* * *}$ & -3.33 & $-0.387^{* * *}$ & -4.18 & $-0.251^{* * *}$ & -2.92 \\
\hline $\begin{array}{l}\text { (EXPORT + IMPORT)/GDP } \\
\text { c) ECONOMIC STRUCTURE }\end{array}$ & -0.036 & -0.38 & -0.024 & -0.23 & -0.057 & -0.72 & -0.063 & -0.84 \\
\hline $\begin{array}{l}1 \text { - AGRICULTURE/GDP } \\
\text { d) REGION }\end{array}$ & & & & & $0.541^{* * *}$ & 5.39 & $0.647^{* * *}$ & 6.15 \\
\hline LATIN AMERICA & -0.036 & -0.53 & -0.111 & -1.62 & $-0.165^{* *}$ & -2.06 & $-0.274^{* * *}$ & -3.36 \\
\hline Observations & 109 & & 109 & & 105 & & 105 & \\
\hline Prob $>$ F & 0.003 & & 0.000 & & 0.000 & & 0.000 & \\
\hline R-squared & 0.196 & & 0.174 & & 0.378 & & 0.413 & \\
\hline
\end{tabular}

Notes: The dependent variables are: TAX EFFORT: tax revenues/GDP, TAX REVENUE: current revenues/GDP. Significance levels: ${ }^{*} 0.05<p<0.10,{ }^{* *} 0.01<p<0.05,{ }^{* * *} p<0.01$. Regressions with robust standard errors. In the reference group: OTHER DEVELOPING AND TRANSITION COUNTRIES.

Quality of Governance Index (see Kaufmann, Kraay, and Mastruzzi (KKM), 2003) This index reports the mean value of six governance dimensions for the periods 1996, 1998 and 2000. It is based on several hundred variables measuring perceptions of governance and derived from 25 different data sources. KKM (2003) classify the six governance indicators into three groups as follows:

1) Process by which governments are selected, monitored and replaced

- VOICE AND ACCOUNTABILITY: measures the political process, civil liberties, and political rights

- POLITICAL STABILITY AND ABSENCE OF VIOLENCE: measures perceptions of the likelihood that the government will be destabilized/overthrown)

2) Capacity of the government effectively to formulate and implement sound policies

- GOVERNMENT EFFECTIVENESS (inputs required for the government to be able to produce and implement good policies and deliver public goods) 
- REGULATORY QUALITY (focuses more on policies, such as incidence of market/unfriendly policies, perceptions of the burdens imposed by excessive regulation)

3) Respect of citizens and the state for the institutions that govern economic and social interactions

- RULE OF LAW (several indicators measuring the degree of agents' confidence in and compliance with the rules of society). According to KKM. (2003, p.4) these indicators "measure the success of a society in developing an environment in which fair and predictable rules form the basis of economic and social interactions"

- CONTROL OF CORRUPTION: measures the perceived corruption (exercise of public power for private gain).

All scores estimated by KKM (2003) lie between -2.5 and 2.5, with higher scores corresponding to better institutions (outcomes). We check the robustness of the statistical results for the governance index by using several combinations of sub-indexes.

International Country Risk Guide (ICRG) (see Knack 1999)

The ICRG provides an alternative set of data to the Quality of Governance Index, with special emphasis on aspects affecting private foreign investment decisions. The data contain annual values for indicators of the quality of governance, 1982-1997, constructed by Stephen Knack and the IRIS Center, University of Maryland and provided by The PRS Group. Our interest is in the Political Risk Components of the ICGR. We derive an index (mean values) based on a selection of the following components from the Political Risk Components: CORRUPTION IN THE GOVERNMENT, ${ }^{24}$ RULE OF LAW ("LAW AND ORDER TRADITION", 25 BUREAUCRATIC QUALITY,${ }^{26}$ ETHNIC TENSION,${ }^{27}$ REPUDIATION OF

\footnotetext{
${ }^{24}$ Lower scores indicate "high government officials are likely to demand special payments" and that "illegal payments are generally expected throughout lower levels of government" in the form of "bribes connected with import and export licenses, exchange controls, tax assessment, police protection, or loans."

${ }^{25}$ This variable "reflects the degree to which the citizens of a country are willing to accept the established institutions to make and implement laws and adjudicate disputes." Higher scores indicate: "sound political institutions, a strong court system, and provisions for an orderly succession of power." Lower scores indicate: "a tradition of depending on physical force or illegal means to settle claims." Upon changes in government new leaders "may be less likely to accept the obligations of the previous regime."

${ }^{26}$ High scores indicate "an established mechanism for recruitment and training," "autonomy from political pressure," and "strength and expertise to govern without drastic changes in policy or interruptions in government services" when governments change.

${ }^{27}$ This variable measures the degree of tension within a country attributable to racial, nationality, or language divisions. Lower ratings are given to countries where racial and nationality tensions are high because opposing groups are intolerant and unwilling to
} 
GOVERNMENT CONTRACTS, ${ }^{28}$ EXPROPRIATION RISK. ${ }^{29}$ A higher number of points indicates a lower potential risk. Most values range between 1 and 6 (exceptions: EXPROPRIATION RISK and REPUDIATION OF GOVERNMENT CONTRACTS which range between 1 and 10).

These two variables, the ICRG Index and the Quality of Governance Index capture some of the 'voice' institutions and, more generally, the quality of the responsiveness of government to citizens' demands. Because of the high correlation (0.72) between the ICRG and the Quality of Governance variables, we use these two sets of variables in alternate estimations. ${ }^{30}$

\subsection{Regulation of Entry}

According to public choice theory, regulations can be used by politicians and bureaucrats to pursue their own benefits, as opposed to the interests of the general public. Regulatory discretion enables bureaucrats to create and extract rents. Bribes are collected in exchange for the selective release from regulation. More generally, bureaucrats have an incentive to delay transactions in order to extract higher payments (see Rose-Ackerman, 1997). But, a main problem with rent creation through regulation is that it "...is often inefficient, in part because the policies they pursue to increase the rents from corruption are distortionary" (Djankov et al., 2002, p. 3). There are situations in many developing countries where if people want to open a business, to acquire land or build homes they are confronted with very high transaction costs, and law-breaking may be the only option to survive. Hernando de Soto (2000) tested the seriousness of barriers to entry by creating a new and perfectly legal small business in Lima. His team spent six hours a day at it and was able to register the business 289 days later. The cost of the legal registration was $\$ 1,231$, or thirty-one times the monthly minimum wage. To obtain the authorization to build a house on state-owned land took six years and 11 months, with 207 administrative

compromise. Higher ratings are given to countries where tensions are minimal, even though such differences may still exist.

28 "This indicator addresses the possibility that foreign businesses, contractors, and consultants face the risk of a modification in a contract taking the form of a repudiation, postponement, or scaling down" due to "an income drop, budget cutbacks, indigenization pressure, a change in government, or a change in government economic and social priorities." Lower scores signify "a greater likelihood that a country will modify or repudiate a contract with a foreign business."

${ }^{29}$ This variable evaluates the risk "outright confiscation and forced nationalization" of property. Lower ratings are given to countries where expropriation of private foreign investment is considered likely.

${ }^{30}$ There is no fixed rule on how highly correlated two variables have to be before multicollinearity becomes a problem. For example, Allison (1999) points out that values above 0.80 almost certainly are problematic, but there may be difficulties that appear below that value. Because the two sets of variables practically measure the same institutions and we are not testing hypotheses about any specific variable, we find it simpler to use them as alternate measures. 
steps in 52 government offices and to obtain legal title to that piece of land took 728 steps. Similar experiences have been described in other countries, e.g., Philippines, Egypt, and Haiti. ${ }^{31}$ As Frey and Eichenberger (1999, p. 89) argue, many developing countries have both "over-government" and "under-government," that is, a strong combination of interventionism and bureaucracy with property rights that are not sufficiently secured and where there is a high degree of uncertainty. In such an environment there are weak incentives for investment and entry in the formal sector.

We use a new data set provided by Djankov et al. (2002) to measure the degree of regulation of faced by start-up companies. The data are for 1999. Djankov et al. (2002) recorded all officially required procedures that a new entrepreneur must go through in order to enter the formal market sector. To check for robustness, we use two measures of regulation: the number of procedures and the official time required to complete the process. Longer delays and more procedures make entry less attractive, facilitate corruption and may lead to a lower tax ratio. The degree of regulation of entry can be seen as a 'voice' institution in reverse, since it measures how unresponsive the government is to business and citizens needs and demands. The regulation of entry is also linked to the 'exit' variables presented in the next subsections, as high level of regulation induces a move to work in the informal sector of the economy.

\subsection{Tax Morale and the Shadow Economy}

A sustainable tax system is based on a fair tax system and responsive government, achieved with a strong connection between tax payments and the supply of public goods. If taxpayers perceive that their preferences are adequately represented and they are supplied with public goods, their identification with the state increases, and thus the willingness to pay taxes rises. We hypothesize that a lower degree of tax morale, defined as the intrinsic motivation to pay taxes, reduces the tax effort in a country. The level of tax effort is also expected to be strongly connected to the "exit option' - the decision to conduct, fully or partially, economic activity in the informal sector (the shadow economy). The more taxpayers believe that others work in the shadow economy, the lower the moral costs to them to behave dishonestly and evade taxes by moving their own activities to the shadow economy. In this way the potential intrinsic motivation to comply and contribute to public sector activities gets crowded out. Thus, we hypothesize that a larger shadow economy should lead to a lower level of tax effort. Measures of tax morale and the shadow economy tend to be

\footnotetext{
${ }^{31}$ Furthermore, de Soto argues that it is nearly as difficult to stay legal, as it is to become legal. In Venezuela, the share of employees working in legal enterprises decreased from two third in 1976 to less than half in our days. Thus, people have created new business illegally to fill the gaps in the legal economy.
} 
highly correlated. Several previous studies have shown that low tax morale might be responsible for the rise of shadow economy (see, e.g., Torgler, 2001, 2004; Alm and Torgler, 2004; Alm, Martinez-Vazquez and Torgler, 2004). For these reasons, tax morale and the shadow economy are employed as alternate measures of the 'exit option' in our empirical analysis.

The size of the shadow economy is measured as a percentage of official GDP, using data from Schneider and Klinglmair (2003). In line with the observations for the dependent variables, we take the average values for 1990, 1995, and 1999. ${ }^{32}$

Data for the tax morale variable are extracted from several surveys: the Latinobarómetro (1998), the World Values Survey (WVS) 1990-1993, 1995-1997 (see Inglehart et al., 2000) and the European Values Survey 1999-2000 (see European Values Study, 1999). Both surveys investigate socio-cultural and political change and collect comparative data on values and belief systems. Both are based on representative national samples of at least 1000 individuals. The World Values Survey (WVS) is worldwide and covers more than 40 countries, while the Latinobarómetro survey is carried out in 17 Latin American countries. The general questions to assess the level of tax morale in the two surveys are:

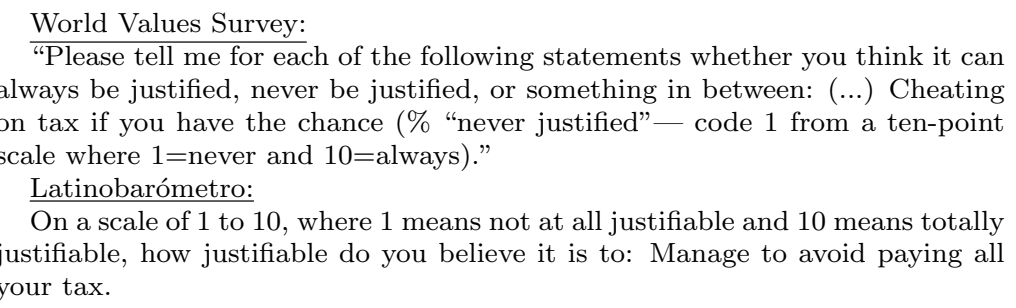

In both cases the tax morale variable is developed by recoding the tenpoint scale into a four-point scale (0 to 3 ), with the value 3 standing for "never justifiable". The value of 0 is an aggregation of the last 7 scale points, which were rarely chosen. ${ }^{33}$ Both surveys cover the period 1990 to 1999.

\footnotetext{
${ }^{32}$ See Schneider and Enste (2002) and Alm, Martinez-Vazquez, and Schneider (2004)for a description of the methodologies used in the estimation of the shadow economy.

${ }^{33}$ Of the two surveys, the World Values Survey provides more observations. On the other hand, the Latinobarómetro allows us to include more Latin American countries in the empirical analysis. Note that the tax morale questions are not identical. Eight Latin American countries (Argentina, Brazil, Chile, Colombia, Mexico, Peru, Uruguay and Venezuela) are available in both data sets. To judge from the average values for the two measures in the two data sets (WVS, 2.215 and Latinobarómetro, 2.113) the variables are almost identical. However, in order to maximize the number of observations, we work with the World Values Survey, which allows us to include other developing and transition countries. The average values for Latin American countries, which can only be constructed from the Latinobarómetro, are multiplied by the factor $(2.215 / 2.113)$
} 


\subsection{Inequality}

As discussed in Section 2, inequality in the distribution of wealth and income is strongly connected with public views as to how well the fiscal system addresses social objectives with respect to fairness, social justice and redistribution. If a perceived unfair distribution of tax burdens is thought to be one cause of income inequality, the result may be to lower the level of trust in institutions and eventually to lower tax effort because of widespread tax avoidance and evasion. Highly unequal distributions of income, as in many Latin American countries, can also lead to low levels of solidarity by the elites toward lower income groups. Low levels of tax effort in Central America, for example, are often interpreted as the result of the unwillingness of the richest small percentage of the population to pay more in taxes to provide public services for the masses since the elite can provide their own 'public services' privately, ranging from public safety to education and even roads. Furthermore, income inequality may be associated with political instability. For example, less privileged groups may choose to use undemocratic instruments to improve their situation (Alesina and Perotti 1996). On the other hand, privileged groups may try to maintain their position by illegal means. In summary, more unequal distributions of income and wealth are likely to enhance the exit option for all types of taxpayers. We hypothesize that higher inequality leads to lower levels of tax effort.

To measure the variable income inequality we use the newest available data set.

ESTIMATED HOUSEHOLD INCOME INEQUALITY (EHII), constructed by Galbraith and Kum (2003). This data set combines the information in the Deininger and Squire (1996) and UTIP-UNIDO (average 1990-1999 and average of the whole data set, 1963-1999). ${ }^{34}$

\subsection{Fiscal Decentralization}

The level of tax effort may also depend on the vertical structure of government, and in particular on the level of fiscal decentralization. Several mechanisms (with opposing impacts) may lead fiscal decentralization to influence tax effort. First, a more decentralized system of government tends to be more responsive and can better meet taxpayers' needs and preferences (Oates 1972). A more efficient and responsive government at all levels may result in an increased willingness to contribute and also in an increased demand for public spending and higher voluntary levels of tax effort. On

to address some scaling effects. This approach allows us to include a larger number of Latin American countries in the analysis.

${ }^{34}$ Galbraith and Kum (2003) estimate gross household income inequality from a regression between the Deiniger and Squire (1996) inequality measures and the UTIPUNIDO pay inequality measures. 
the other hand, a more decentralized system of government imposes more restrictions on the ability of government to act as a Leviathan exploiting tax bases and increasing public spending since taxpayers may select jurisdictions with lower levels of expenditures and taxes and jurisdictions may compete among themselves to keep taxes and expenditures low (Brennan and Buchanan, 1980). There is some empirical cross-country evidence that higher levels of decentralization lead to lower levels of public expenditure (Arze, Martinez-Vazquez, and McNab, 2004) Furthermore, decentralization may encourage governments to rely more on user charges and fees and less on taxes, so that consumers are more likely to be confronted with the marginal costs of public service delivery (Feld, Kirchgässner and Schaltegger 2003), and such charges and fees may not be recorded as government tax revenues. A greater level of decentralization and autonomy at the local level may thus lead to lower levels of tax effort although this prediction is not unambiguous.

Several other considerations should be mentioned. First, the similarity of some of the explanatory variables and multicollinearity does not allow us to run full specifications including all the potential institutional explanatory variables identified above. Our approach is therefore to run a series of estimations in which some institutional variables are replaced by others, usually from different data sources. One advantage of this approach is that it permits us to check the robustness of the estimated effect of institutions on tax and revenue ratios.

Second, some of the institutional variables may be endogenous. For example, better institutions may lead to better tax performances, but in turn, poor tax performance can reduce the possibilities of establishing or maintaining well functioning institutions in developing and transition countries. To check for the presence of endogeneity, we conduct a Hausman Chisquare test for each estimation. In those cases where exogeneity cannot be rejected, we use a 2SLS approach, as indicated in the tables showing the results. ${ }^{35}$

\footnotetext{
${ }^{35}$ In general, as Kaufmann, Mehrez and Gurgur (2002) point out, the choice of an estimator in a small sample situation is still an econometric puzzle: for example, OLS estimators are often found to be close to an instrumental variable technique in many empirical studies. An important problem is that 2SLS produce biased estimators in small samples (see also Green 2000). The choice of adequate instruments for institutions is not extensively addressed in the literature (for corruption see, e.g., Kaufmann, Kraay and Zoido-Lobatón 1999, Bai and Wei 2000, Kaufmann, Mehrez and Gurgur 2002). More recent studies stress the relevance of considering historical and geographic features of the countries as instrumental variables as they influence the outcome through their impact on the institutional and political environment (see, e.g., Hall and Jones 1999, and Acemoglu, Johnson and Robinson, 2001). Recent studies such as the ones of Alesina et al. (2002) or La Porta et al. (1999) offer a broad data set to consider factors such as latitude, ethnic fractionalization, language, and religion. Taking into consideration that the instruments need to be highly correlated with the regressor for which it is acting as
} 
As data for the institutional variables are derived from different sources, we first present estimations focusing on different institutional factors independently. This approach allows us to look at results for the different variables when we are able to maximize the number of observations. Subsequently, we present the results for fuller specifications. A fuller specification has the obvious advantage of presenting a more balanced view of the role of different institutions (separating the effects of the independent variables) but it has the disadvantage that the number of observations we can utilize is smaller, perhaps resulting in other types of biases.

The empirical results presented in Tables 2 to 7 suggest strongly that institutions play a significant role in the determination of the level of tax effort of developing and transition countries. Though the conventional supply factors continue to play a robust and significant role throughout the estimations, demand factors clearly matter.

The joint role played by the demand factors can be investigated using a Wald-test for coefficient restrictions to test for joint significance. In most cases the F-statistics indicate that the null hypothesis is rejected, meaning that the demand factors play a significant role in the determination of countries' tax performance. The relative role played by demand factors vis-à-vis supply factors is investigated by estimating beta or standardized regression coefficients. The results in Tables 2 to 7 show that demand side determinants are highly relevant in explaining tax performance in transition and developing countries. These variables show relatively high beta coefficients, comparable or even higher than the traditional supply factors.

One last general result in Tables 2 to 7 is that Latin American countries show consistently lower tax performance by comparison to other developing and transition countries. This again provides statistical support to our discussion in the previous section of this paper.

an instrument, our data set indicates that historical and geographic variables perform very well as instruments. 


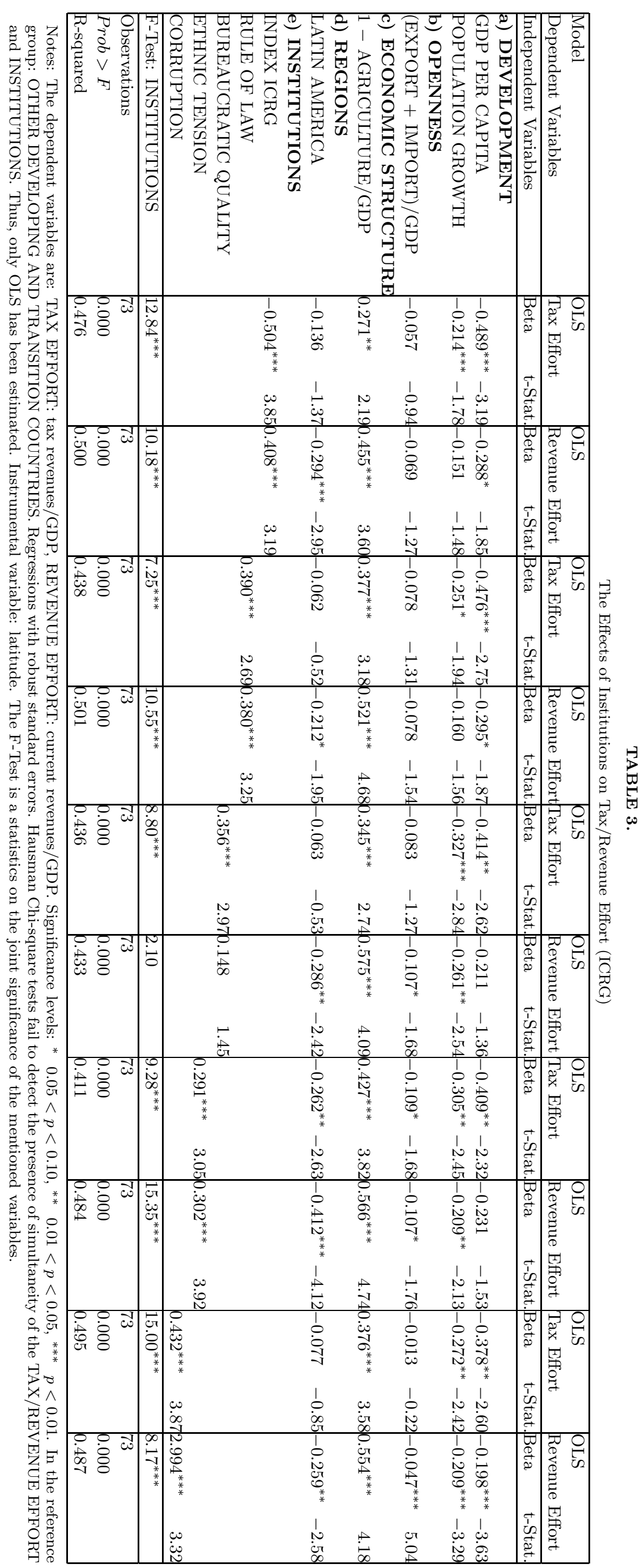




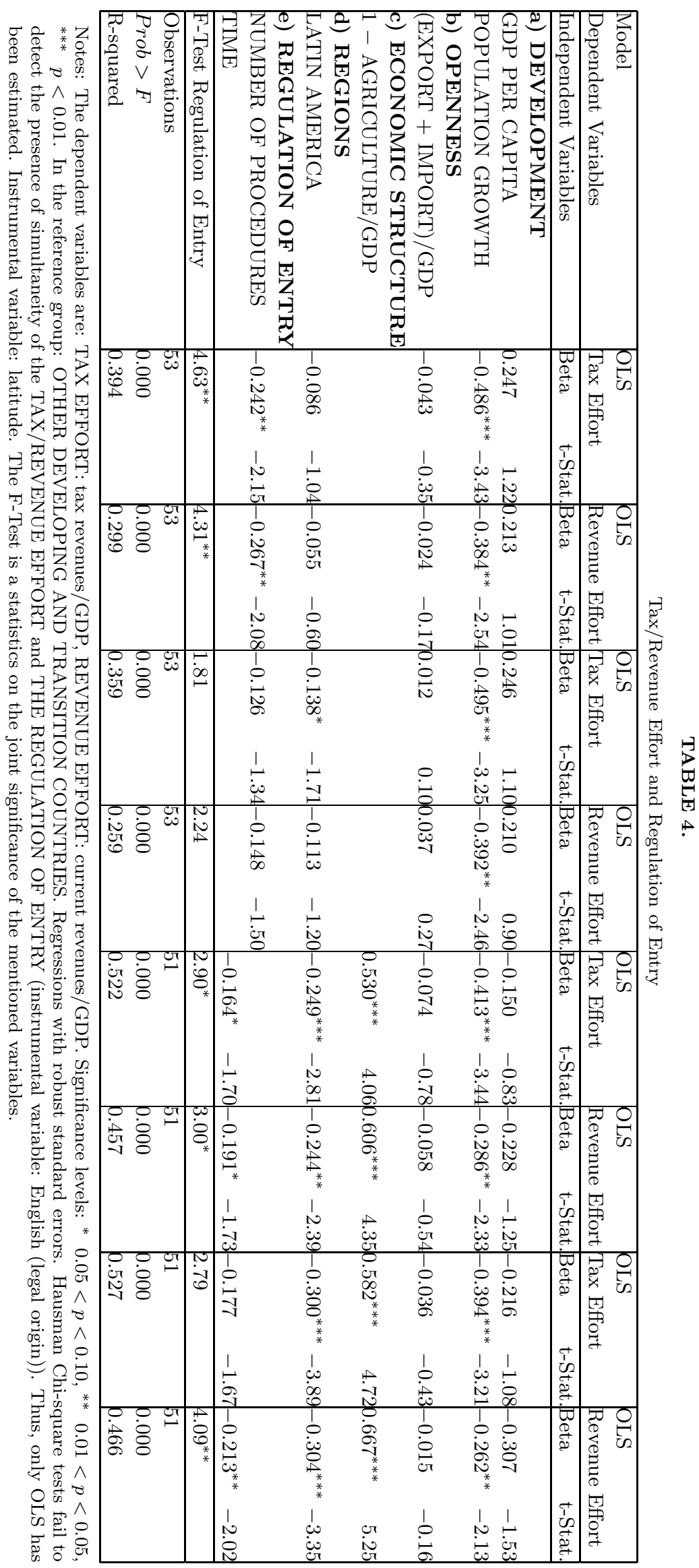




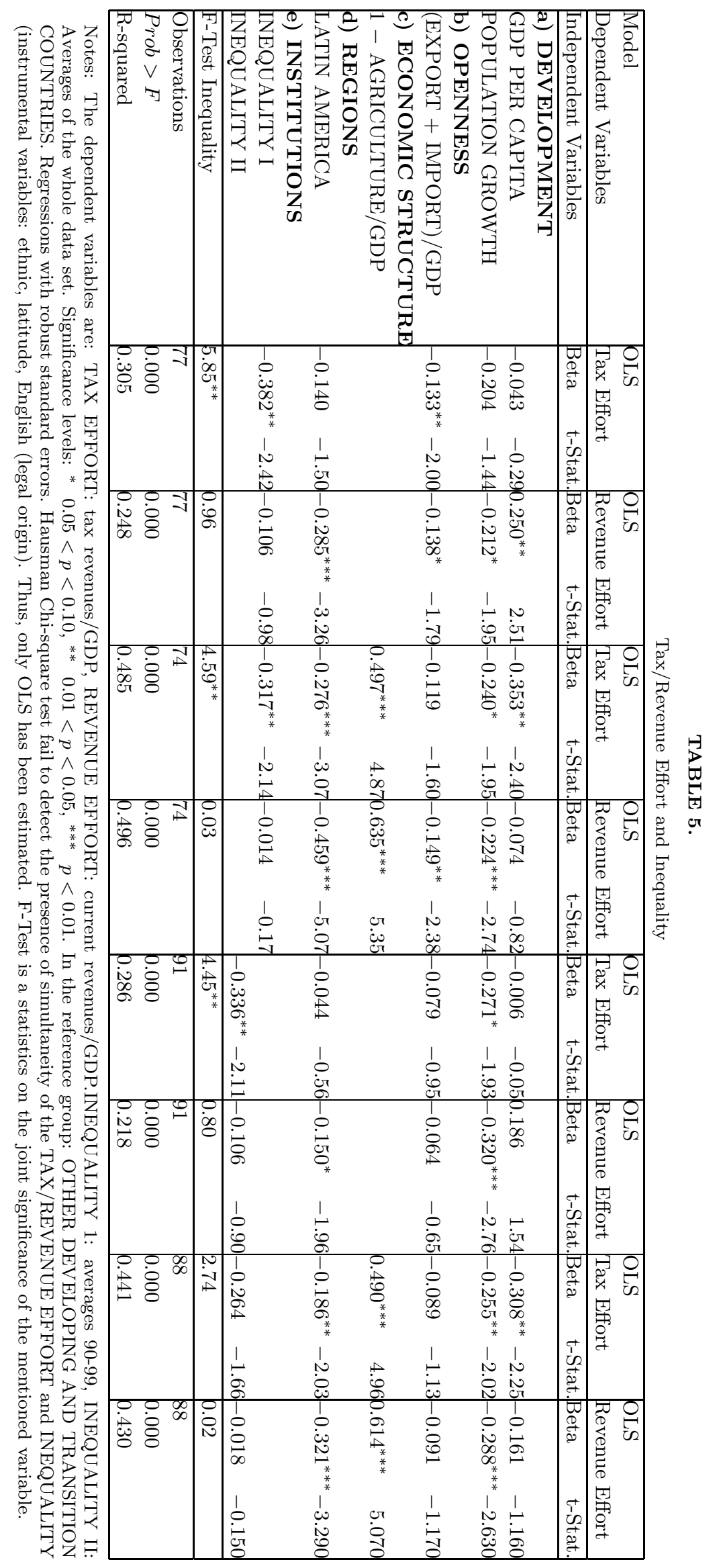




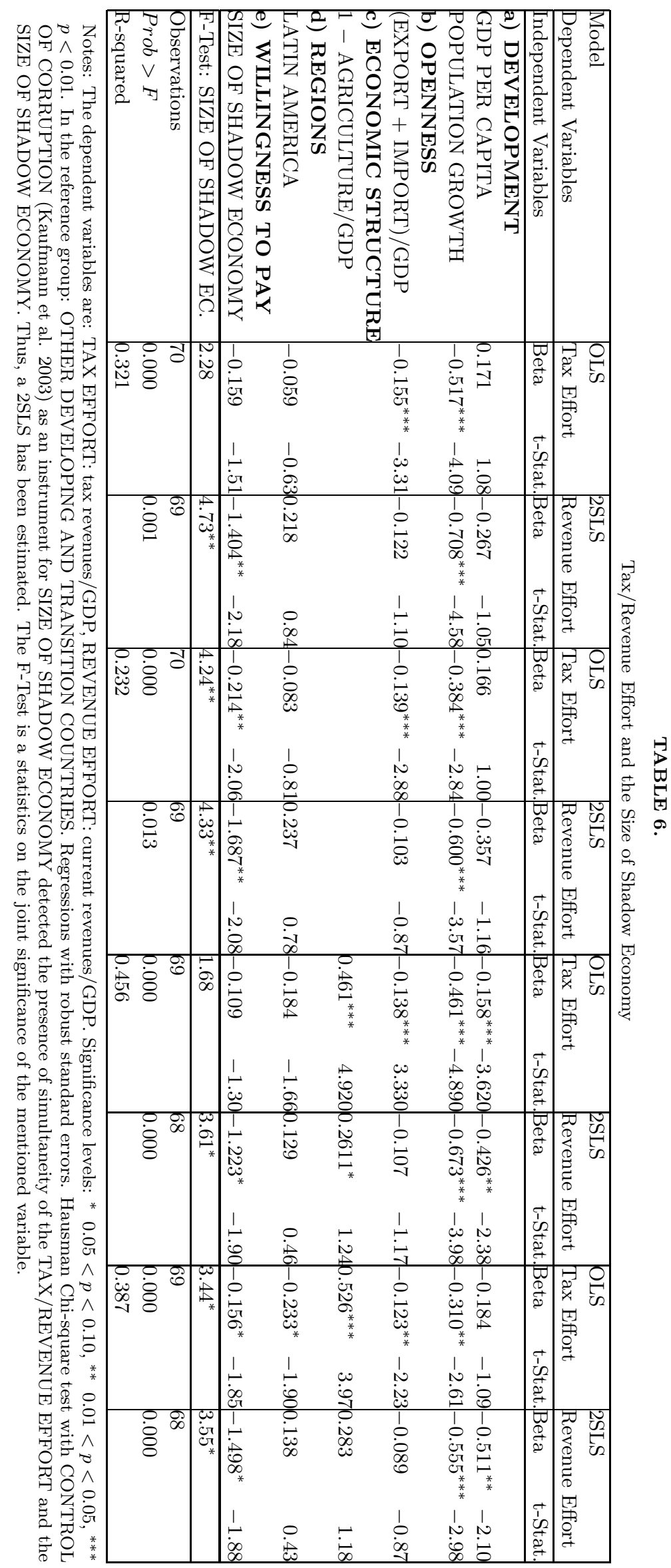




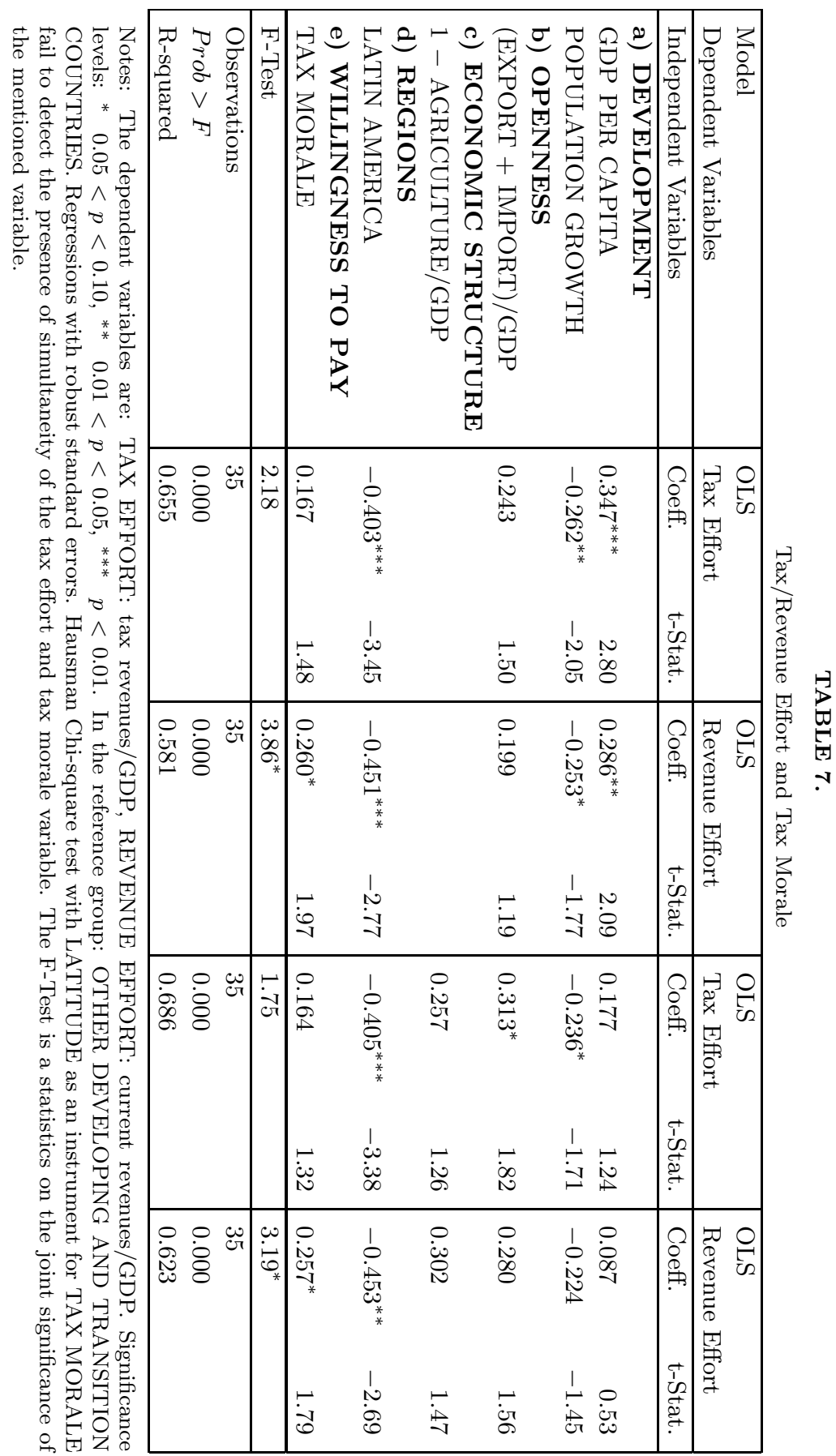




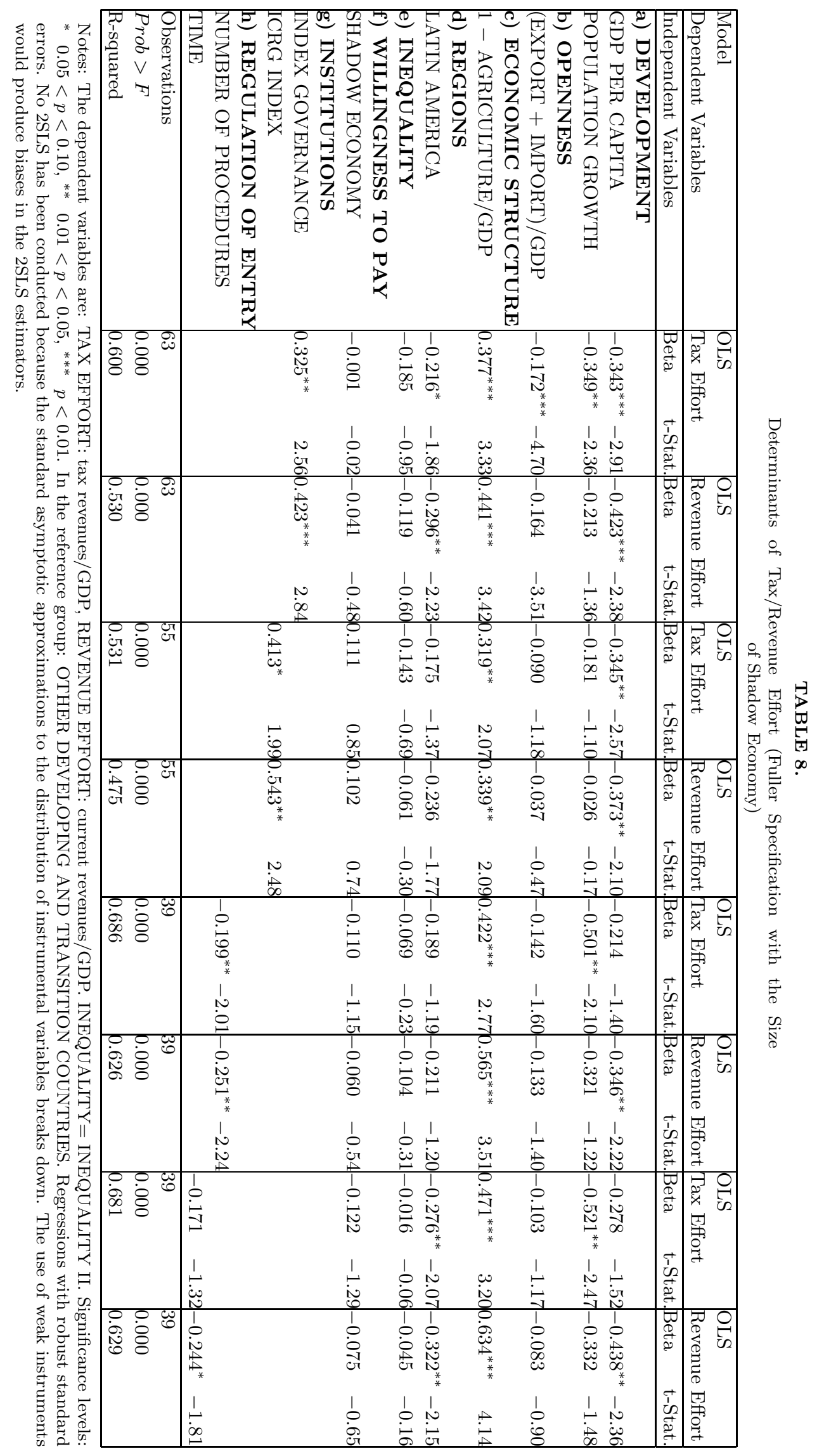




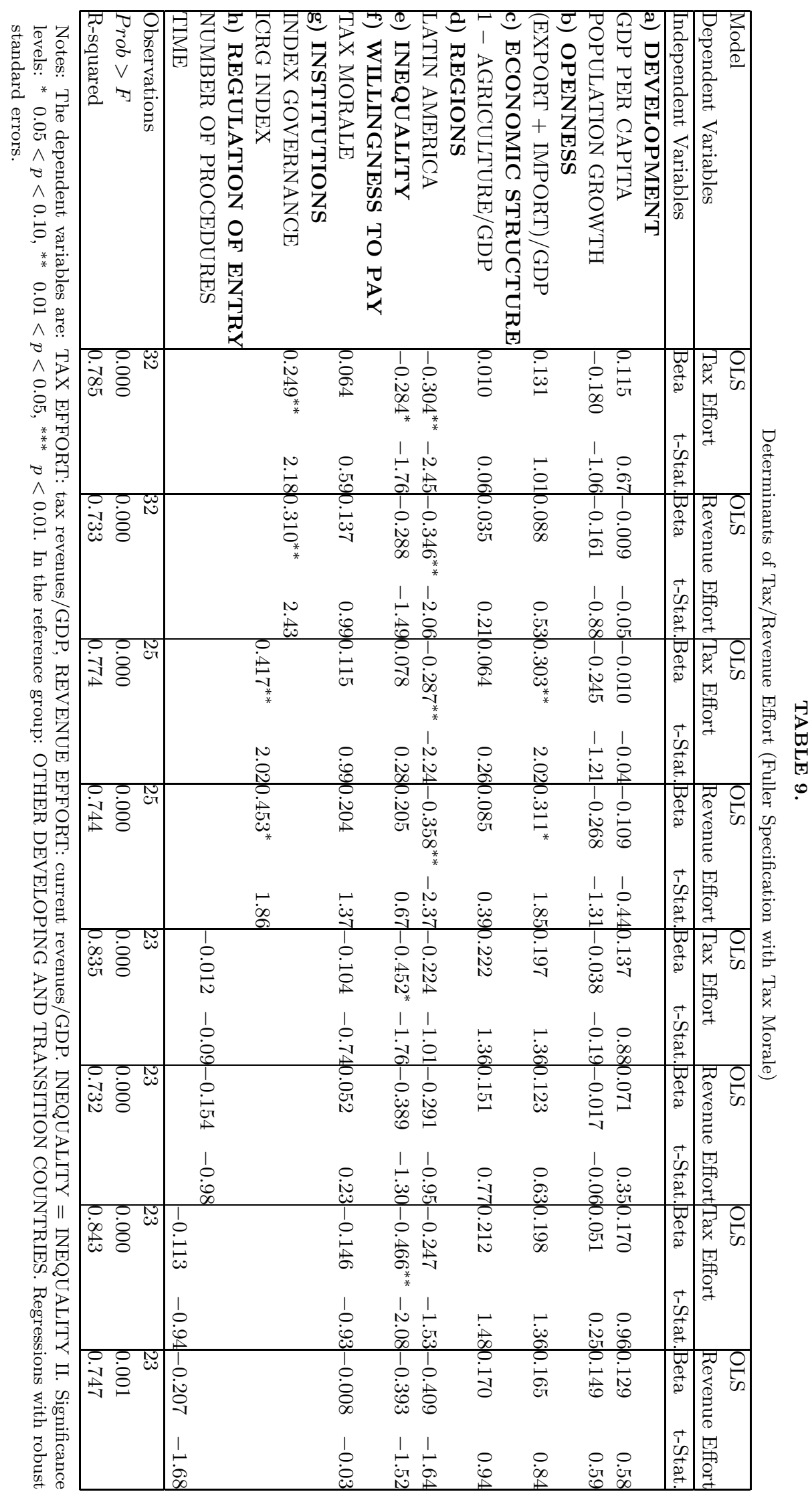


Let us now consider the estimates for individual variables. The role of 'voice' institutions as measured by the Quality of Governance and the ICRG variables is explored in Tables 2, 3 and 4 respectively. The main indexes and the sub-indexes have coefficients with the expected sign and are highly significant. Among the selected sub-indexes, corruption and the rule of law seem to play key roles in explaining the level of tax effort. A higher regulated entry also leads to a lower tax/revenue effort. However, we observe a lower impact compared to the other voice variables. In general, these results give support to the hypothesis that societies' willingness to tax themselves depends on the perception that government institutions are honest and responsive and that there is a fair and predictable public sector environment.

The role of 'exit' variables is explored in Table 5 for income inequality, Table 6 for the size of the shadow economy, and Table 7 for tax morale. In most cases, these variables take the expected sign and in many cases the coefficient are statistically significant. Where disparities in the distribution of income are larger, or the size of the shadow economy is bigger, or tax morale is lower, countries tend to show a lower tax effort. However, it seems that the impact is less strong in relation to the 'voice' determinants.

To get a better idea about the strength of the voice and the exit variables, we present in the next two tables fuller specifications with both types of determinants in the same equation. The results are shown in Table 8 (using the shadow economy as the exit variable) and in Table 9 (using tax morale as the exit variable.) These results indicate that both supply (tax handles) and demand variables (institutions) play a significant role in the determination of tax effort. ${ }^{36}$ Among the demand side variables, the voice variables Quality of Governance and ICRG indexes and the regulation of entry variables, take the expected sign and are statistically significant. On the other hand, the exit variables measured by the shadow economy, tax morale and inequality perform less well. Although in some cases coefficients take the right sign and are significant, more often they are statistically insignificant. Thus, it would seem that, overall, voice institutions together with inequality in the distribution of income play a stronger role in the level of tax effort. However, one should be cautious in concluding that exit institutions have only a small effect. For example, exit institutions may mediate the effect of voice institutions in developing countries. Alternatively, causality may run the other way, from voice to exit. ${ }^{37}$ The lack of

\footnotetext{
${ }^{36}$ We also ran the full specifications with fiscal decentralization as an additional explanatory variable. The results consistently showed the decentralization coefficient to be negative, indicating that more decentralized systems may exert lower tax effort, but the coefficients were never statistically significant.

${ }^{37}$ It is difficult to get a clear notion of the causal links among these variables. In most developed countries, for instance, given that good governance and other institutions
} 
significance of the tax morale variable in Table 9 may also be partly due to the low number of degrees of freedom.

We summarize the entire set of empirical findings in Table 10. Among the traditional supply side factors, the sectoral composition of a country's economy (non-agriculture share in GDP) has the strongest impact on tax performance. From the side of the demand factors, voice variables, especially for the Quality of Governance and ICRG indexes, yield the most robust results.

TABLE 10.

Summary of the Results

\begin{tabular}{|l|c|c|c|c|c|}
\hline \multirow{2}{*}{ Model } & \multicolumn{2}{|c|}{$\begin{array}{c}\text { Estimations without } \\
\text { Societal Institutions }\end{array}$} & $\begin{array}{c}\text { Estimations without } \\
\text { Societal Institutions }\end{array}$ & $\begin{array}{c}\text { Estimations without } \\
\text { Societal Institutions }\end{array}$ \\
\cline { 2 - 6 } & Tax Effort & Revenue Effort & Tax Effort & Revenue Effort & Tax Effort \\
Revenue Effort
\end{tabular}

Notes: +/-: always significant positive or negative coefficents, $(+/-)$, positive, respectively negative coefficients sign, but not always statistically significant, $((+/-))$ positive or negative sign of the coefficients without being statistically significant. The summary about the fuller specifications is based on the results obtained in Table 8 and not Table 9 (exception: tax morale), because of the low number of observations in Table 9. 


\section{CONCLUSION}

The main theme of this paper is that a more legitimate and responsive state appears to be an essential precondition for a more adequate level of tax effort in developing countries. While at first glance giving such advice to poor countries seeking to increase their tax ratios may not seem more helpful than telling them to find oil, it is presumably more feasible for people to improve their governing institutions than to rearrange nature's bounty. Furthermore, improving social institutions, such as enhancing the rule of law and reducing corruption, may not take longer nor be necessarily more difficult than changing the opportunities for tax handles and economic structure, such as the relative share of the non-agriculture sector in the economy or the weight of imports and exports in GDP.

The most important contribution of this paper has been to extend the conventional model of tax effort by showing that not only do supply factors matter, but that societal institutions or demand factors common to all countries also matter quite significantly in the determination of tax effort. Of course, in order to fully understand the performance of any one country one needs to pay close attention to the factors that are particular to that country. To return to where we began, in Kaldor's terms, countries have indeed 'learned to tax'...to the extent that their societal institutions lead them to do so.

\section{APPENDIX A}




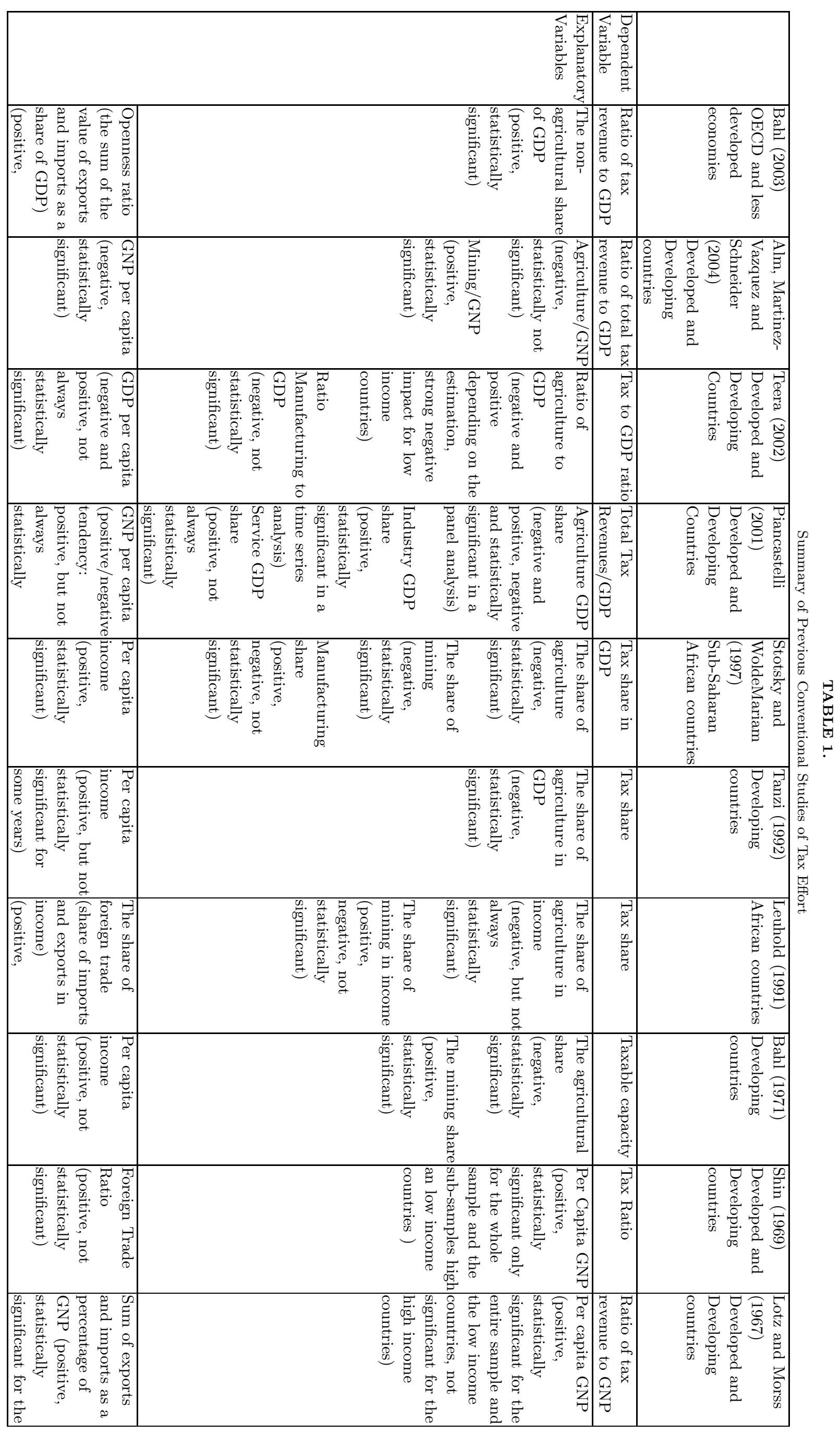




\begin{tabular}{|c|c|c|c|}
\hline & 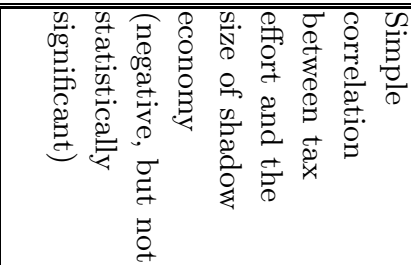 & 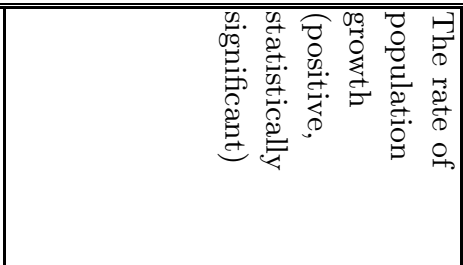 & 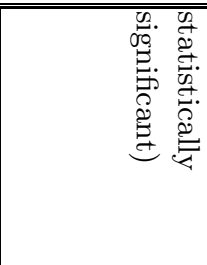 \\
\hline & 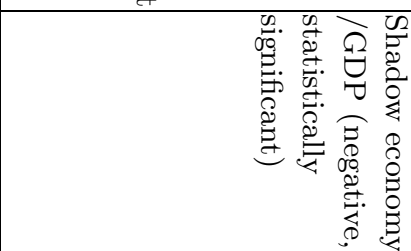 & 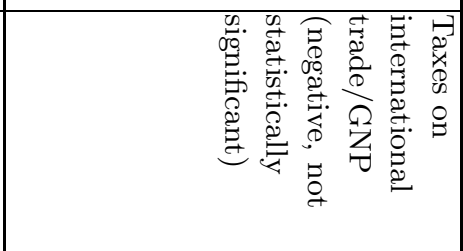 & \\
\hline 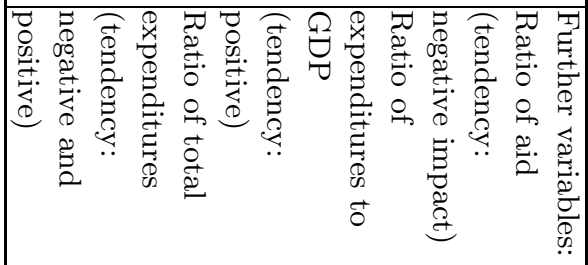 & 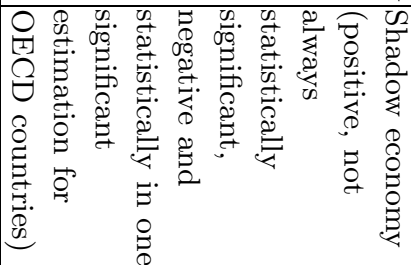 & 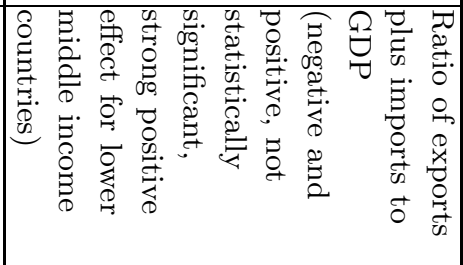 & \\
\hline & & 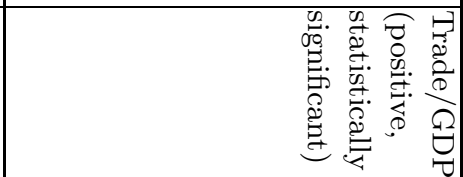 & 然. \\
\hline & & 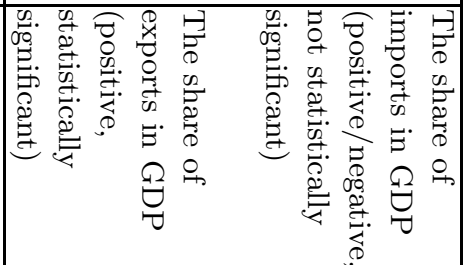 & \\
\hline & 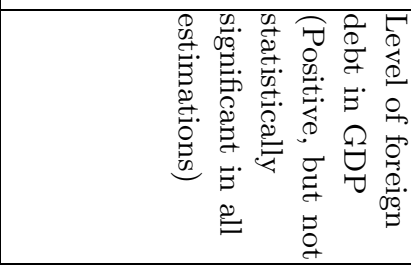 & 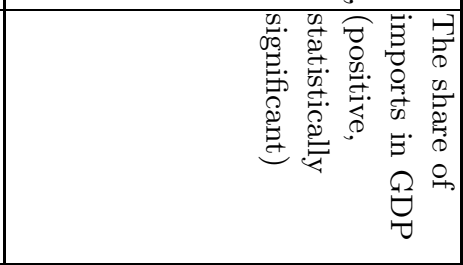 & \\
\hline & & 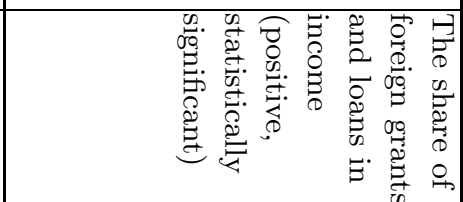 & 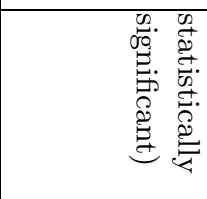 \\
\hline & & 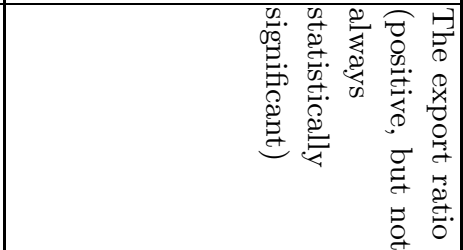 & \\
\hline 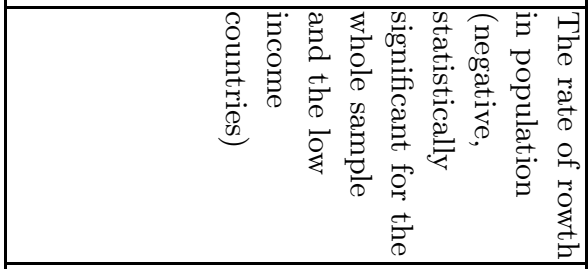 & 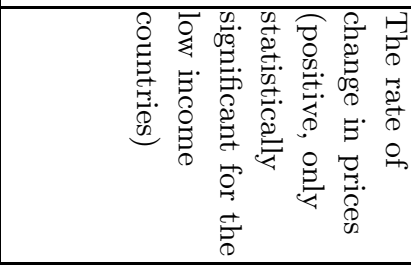 & 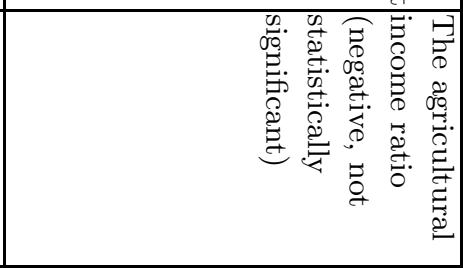 & \\
\hline & & & 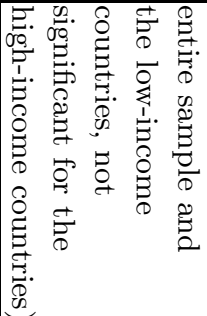 \\
\hline
\end{tabular}




\section{APPENDIX B}

TABLE 1.

Descriptive Statistics for Tax Effort

\begin{tabular}{lllll}
\hline Variable & Observations & Mean & Min & Max \\
\hline Total Data Set & & & & \\
TAX EFFORT & 110 & 17.88 & 1.09 & 38.33 \\
REVENUE EFFORT & 110 & 22.27 & 2.48 & 46.38 \\
\hline Latin America & & & & \\
TAX EFFORT & 23 & 17.78 & 9.98 & 25.96 \\
REVENUE EFFORT & 23 & 20.95 & 12.64 & 29.42 \\
\hline
\end{tabular}

APPENDIX C 


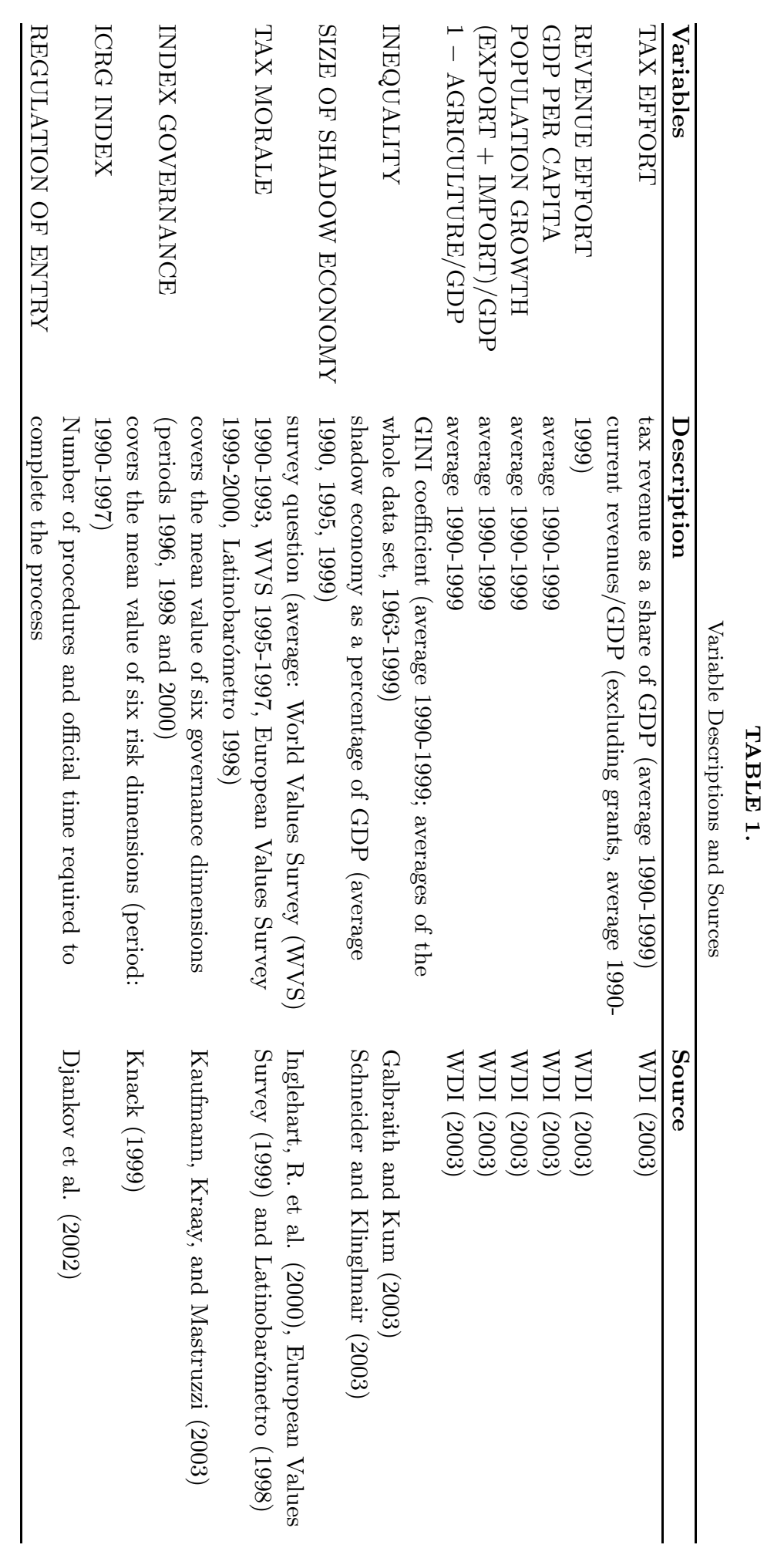




\section{REFERENCES}

Acemoglu, D. S. Johnson and J. Robinson, 2001. The Colonial Origins of Comparative Development: An Empirical Investigation. American Economic Review 91, 13691401.

Allison, P. D., 1999. Multiple Regression: A Primer. California: The Pine Forge Press. Alm, J. and J. Martinez-Vazquez, 2003. Institutions, Paradigms, and Tax Evasion in Developing and Transition Countries, in: J. Martinez-Vazquez and J. Alm (eds.), Public Finance in Developing and Transitional Countries. Cheltenham, UK: Edward Elgar: 146-178.

Alm, J., J. Martinez-Vazquez and Friedich Schneider, 2004. 'Sizing' the Problem of the Hard-To-Tax, paper presented at the "Hard to Tax: An International Perspective" in J.Alm, J. Martinez-Vazquez, and S. Wallace (eds.) Taxing the Hard-to-Tax , Elsevier: Amsterdam.

Alm, J. and B. Torgler, 2004. Culture Differences and Tax Morale in the United States and in Europe, CREMA Working Paper 2004-14, Basel, Center for Research in Economics, Management and the Arts.

Alm, J., J. Martinez-Vazquez and B. Torgler, 2004. Tax Morale in Russia, unpublished manuscript, Georgia State University.

Alesina, A. and G.-M. Angeletos, 2003. Fairness and Redistribution: U.S. versus Europe. Working Paper 9502, National Bureau of Economic Research, Cambridge MA, February.

Alesina, A. and R. Perotti, 1996. Income Distribution, Political Instability, and Investment. European Economic Review 40, 1203-1228.

Alesina, A., A. Devleeschauwer, W. Easterly, S. Kurlat and R. Wacziarg, 2002. Fractionalization. NBER Working Paper No. 9411.

Arze, Javier, Jorge Martinez-Vazquez and Robert Mcnab, 2004. Fiscal Decentralization and the Composition of Public Expenditures. ISP Working Paper, Andrew Young School of Policy Studies, Georgia State University.

Bahl, R. W., 1971. A Regression Approach to Tax Effort and Tax Ratio Analysis. International Monetary Fund Staff Paper 18, 570-612.

Bahl, R. W., 2003. Reaching the Hardest to Tax: Consequences and Possibilities, paper presented at the "Hard to Tax: An International Perspective" conference, Andrew Young School of Policy Studies, Georgia State University, May 15-16.

Bai, C.-E. and S-J. Wei, 2000. The Quality of the Bureaucracy and Capital Account Policies, World Bank Working paper 2575.

Barro, R. J., 1997. Determinants of Economic Growth: A Cross-Country Empirical Study. Cambridge, MA: MIT Press.

Bauer, P., 1955. The Economic Development of Nigeria. Journal of Political Economy 63 (October), 399-408.

Best, M. H., 1976. Political Power and Tax Revenues in Central America. Journal of Development Economics 3, 49-82.

Bird, R. M., 1974. Taxing Agricultural Land in Developing Countries (Cambridge, MA: Harvard University Press).

Bird, R. M., 1976. Assessing Tax Performance in Developing Countries: A Critical Review of the Literature. Finanzarchiv 34, 244-65.

Bird, R. M., 1989. The Administrative Dimension of Tax Reform in Developing Countries, in Malcolm Gillis, ed., Tax Reform in Developing Countries (Durham: Duke University Press). 
Bird, R. M., 2003. Taxation in Latin America: Reflections on Sustainability and the Balance between Equity and Efficiency. ITP Paper 0306, International Tax Program, Joseph L. Rotman School of Management, University of Toronto, June.

Bird, R. M., 2004. Managing Tax Reform. Bulletin for International Fiscal Documentation 58, 42-55.

Bird, R. M. and M. Casanegra de Jantscher, 1992. Improving Tax Administration in Developing Countries (Washington: International Monetary Fund).

Bird, R. M. and E. Zolt, 2003. Introduction to Tax Policy. World Bank Course on Practical Issues in Tax Policy in Developing Countries, April.

Blyth, M, 2002. Great Transformations: Economic Ideas and Institutional Change in the Twentieth Century (Cambridge: Cambridge University Press).

Brennan, G. and J. M. Buchanan, 1980. The Power to Tax: Analytical Foundations of a Fiscal Constitution. Cambridge, Cambridge University Press.

Breton, A., 1996. Competitive Governments (Cambridge: Cambridge University Press).

Cheibub, J. A., 1998. Political Regimes and the Extractive Capacity of Governments: Taxation in Democracies and Dictatorships. World Politics 50, 349-76.

Chelliah, R. J., 1971. Trends in Taxation in Developing Countries. International Monetary Fund Staff Papers 18, 254-331.

Davis, J. M., R. J. Ossowski, and A. Fedelino, eds., 2003. Fiscal Policy Formulation and Implementation in Oil-Producing Countries (Washington: International Monetary Fund).

De Ferranti, D. et al., 2004. Inequality in Latin America (Washington: World Bank).

Deininger, K. and L. Squire, 1996. A New Data Set Measuring Income Inequality. World Bank Economic Review 10, 565-591.

De Soto, H., 2000. The Mystery of Capital: Why Capitalism Triumphs in the West and Fails Everywhere Else. New York: Basic Books.

Dorner, P., 1992. Latin American Land Reforms in Theory and Practice: A Retrospective Analysis (Madison: The University of Wisconsin Press).

Djankov, S., R. La Porta, F. Lopez-de-Silanes and A. Shleifer, 2002. The Regulation of Entry. Quarterly Journal of Economics CXVII, 1-37.

Ebrill, L. et al., 2001. The Modern VAT (Washington: International Monetary Fund).

Engerman, S. L. and K. L. Sokoloff, 2001. Inequality, Institutions and Differential Patterns of Growth among New World Economies. National Bureau of Economic Research European Values Study, 1999. Questionnaire, Tilburg University.

Feld, L. P., G. Kirchgässner and C. A. Schaltegger, 2003. Decentralized Taxation and the Size of Government: Evidence from Swiss State and Local Governments, paper presented at the National Tax Association Conference, Chicago, November.

Frey, B. S., 1997. Not Just for the Money. An Economic Theory of Personal Motivation. Cheltenham, UK, Edward Elgar Publishing.

Frey, B. S. and R. Eichenberger, 1999. The New Democratic Federalism for Europe. Cheltenham, UK, Edward Elgar.

Galbraith, J. K. and H. Kum, 2003. Estimating the Inequality of Household Income: Filling Gaps and Fixing Problems in Deininger \& Squire, UTIP Working Paper No. 22, October. 
Hall, R. and C. Jones, 1999. Why Do Some Countries Produce so Much More per Worker than Others? Quarterly Journal of Economics 114, 83-116.

Harberger, A. C., 2003. Reflections on Distributional Considerations and the Public Finances, Module for World Bank Course on Practical Issues of Tax Policy in Developing Countries, April.

Hettich, W. and S. L. Winer, 1999. Democratic Choice and Taxation. (Cambridge: Cambridge University Press).

Hinrichs, H. H., 1966. A General Theory of Tax Structure Change during Economic Development (Cambridge, MA: Harvard Law School International Tax Program).

Hirschman, A. O., 1971. Exit, Voice and Loyalty (Cambridge, MA: Harvard University Press).

IDB, 1997. Inter-American Development Bank, Latin America after a Decade of Reforms. Economic and Social Progress in Latin America 1997 (Washington).

IDB, 1998. Inter-American Development Bank, Facing Up to Inequality in Latin America. Economic and Social Progress in Latin America 1998-99 (Washington).

Inglehart, R. et al., 2000. Codebook for World Values Survey. Ann Arbor: Institute for Social Research.

Kaldor, N., 1963. Will Underdeveloped Countries Learn to Tax? Foreign Affairs 41, 410-19.

Kaufmann, D., A. Kraay and P. Zoido-Lobatón, 1999. Governance Matters, World Bank Policy Research Working Paper 2195.

Kaufmann, D., G. Mehrez and T. Gurgur, 2002. Voice or Public Sector Management? An Empirical Investigation of Determinants of Public Sector Performance Based on a Survey of Public Officials, unpublished manuscript, World Bank.

Kaufmann, D., A. Kraay, M. Mastruzzi, 2003. Governance Matters III: Governance Indicators for 1996-2002, World Bank, June, 30.

Keynes, J. M., 1936. The General Theory of Employment, Interest and Money (London: Macmillan).

Knack, S., 1999. Aid Dependence and the Quality of Governance, IRIS Center, Working Paper, University of Maryland.

Latinobarómetro, 1998. Codebook 1998. Chile: Corporación Latinobarómetro.

La Porta, R., F. Lopez-de-Silanes, A. Shleifer, and R. Vishny, 1999. The Quality of Government. Journal of Law, Economics, 8 Organization 15, 222-278.

Leuthold, J. H., 1991. Tax Shares in Developing Economies: A Panel Study. Journal of Development Economics 35, 173-185.

Levi, M., 1988. Of Rule and Revenue (Berkeley: University of California Press).

Lindert, P. H., 2002. Why the Welfare State Looks Like a Free Lunch. UC Davis Department of Economics Working Paper 02-7, November.

Lindert, P. H., 2003. Growing Public: Social Spending and Economic Growth Since the Eighteenth Century, vol. 1 (Cambridge UK: Cambridge University Press).

Lindert, P. H., 2004. Voice and Growth; Was Churchill Right? Journal of Economic History 63 (No. 2), 315-50.

Lledo, V. A. Schneider, and M. Moore, 2003. Pro-poor Tax Reform in Latin America: A Critical Survey and Policy Recommendations, IDS, Sussex, March.

Lotz, J. R. and E. R. Morss, 1967. Measuring 'Tax Effort' in Developing Countries. International Monetary Staff Papers 14, 479-497. 
Martin, A. and W. A. Lewis, 1956. Patterns of Public Revenue and Expenditure. Manchester School of Economic and Social Studies 24 (September), 203-44.

Martinez-Vazquez, Jorge, 2001. Mexico: An Evaluation of the Main Features of the Tax System. International Studies Program Working Paper 01-12. Atlanta, Georgia: Andrew Young School of Policy Studies, November.

McLure, C. E. and G. Zodrow, 1997. Thirty Years of Tax Reform in Colombia, in W.R. Thirsk, ed., Tax Reform in Developing Countries (Washington: World Bank).

Messere, K. F. de Kam, and C. Heady, 2003. Tax Policy: Theory and Practice in OECD Countries (London: Oxford University Press).

Musgrave, R. A., 1969. Fiscal Systems (New Haven: Yale University Press).

Oates, W. E., 1972. Fiscal Federalism. New York: Harcourt Brace Jovanovich.

Peacock, A. T. and J. Wiseman, 1967. The Growth of Public Expenditures in the United Kingdom, Allen and Unwin, London.

Piancastelli, M., 2001. Measuring the Tax Effort of Developed and Developing Countries. Cross Country Panel Data Analysis / 1985/95, Discussion Paper, IPEA, Rio de Janeiro, September.

Rodrik, D., A. Subramanian, and F. Trebbi, 2002. Institutions Rule: The Primacy of Institutions over Geography and Integration in Economic Development, NBER 9305, National Bureau of Economic Research, Cambridge, MA., November.

Rose-Ackerman, S., 1997. The Political Economy of Corruption, in: K. A. Elliott (ed.). Corruption and the Global Economy. Washington D.C.: Institute for International Economics: 31-60.

Sabates, R. and A. Schneider, 2003. Taxation, Accountability and the Poor, Seminar Report, Institute of Development Studies, University of Sussex.

Schneider, F. and D. H. Enste, 2002. The Shadow Economy. An International Survey. Cambridge: Cambridge University Press.

Schneider, F. and R. Klinglmair, 2003. Shadow Economies Around the World: What Do we Know?, paper presented at the Annual Public Choice Conference in Baltimore, March, 2004.

Shin, K., 1969. International Difference In Tax Ratio. The Review of Economics and Statistics 51, 213-220.

Shome, P., 1999. Taxation in Latin America: Structural Trends and Impact of Administration, IMF Working Paper WP/99/19.

Stotsky, J. G. and A. WoldeMariam, 1997. Tax Effort in Sub-Saharan Africa, IMF Working Papers No. 97/107, International Monetary Fund, September.

Stotsky, J. G. and A. WoldeMariam, 2002. Central American Tax Reform: Trends and Possibilities, IMF Working Paper WP/02/227, Washington, December.

Tanzi, V., 1987. Quantitative Characteristics of the Tax Systems of Developing Countries, in David Newbery and Nicholas Stern, eds., The Theory of Taxation in Developing Countries (Published for the World Bank by Oxford University Press).

Tanzi, V., 1992. Structural Factors and Tax Revenue in Developing Countries: A Decade of Evidence, in: I. Goldin and L. A. Winters (eds.), Open Economies: Structural Adjustment and Agriculture. Cambridge: Cambridge University Press: 267-281.

Teera, J., 2002. Tax Performance: A Comparative Study, Working Paper 01-02, Centre for Public Economics, University of Bath.

Teng, J., 2001. Endogenous Authoritarian Property Rights. Journal of Public Economics $\mathbf{7 7}$ (No. 1), 81-95. 
Torgler, B., 2001. Is Tax Evasion Never Justifiable? Journal of Public Finance and Public Choice 19, 143-168.

Torgler, B., 2004. Tax Morale in Latin America, forthcoming in: Public Choice.

Warriner, D., 1969. Land Reform in Theory and Practice (Oxford: Clarendon Press). Weisman, S. R., 2002. The Great Tax Wars (New York: Simon and Schuster).

Wicksell, K., 1896. Finanztheoretische Untersuchungen nebst Darstellung and Kritik des Steuerwesens Schwedens. Jena: Gustav Fischer.

Youngman, J., 2002. Enlarging the Property Tax Debate - Regressivity and Fairness. State Tax Notes October 7, 45-52. 